\title{
Post-Glacial Relative Sea-Level Observations from Ireland and Their Role in Glacial Rebound Modelling
}

Anthony J. Brooks, ${ }^{1}$ Sarah L. Bradley,${ }^{2}$ Robin J. Edwards, ${ }^{1 \star}$ Glenn A. Milne, ${ }^{2}$ Ben Horton ${ }^{3}$ and Ian Shennan ${ }^{4}$

\footnotetext{
${ }^{1}$ School of Natural Sciences, Trinity College Dublin, Ireland

${ }^{2}$ Department of Earth Sciences, University of Durham, UK

${ }^{3}$ Department of Earth \& Environmental Science, University of Pennsylvania, USA.

${ }^{4}$ Department of Geography, University of Durham, UK.

*Correspondent - Email: edwardsr@tcd.ie; Tel: +353 1896 1713; Fax: +353 16711397
}

[Citation: Brooks, A.J., Bradley, S.L., Edwards, R.J., Milne, G.A., Horton, B.P., Shennan, I. (2008) Post-Glacial Relative Sea-Level Observations from Ireland and Their Role in Glacia Rebound Modelling. Journal of Quaternary Science 23(2), 175-192. DOI: 10.1002/jqs.1119]

\section{ABSTRACT}

The British Isles have been the focus of a number of recent modelling studies owing to the existence of a high quality sea-level data set for this region and the suitability of these data for constraining shallow Earth viscosity structure, local to regional ice sheet histories and the magnitude/timing of global melt water signals. Until recently, the paucity of both glaciological and relative sea-level (RSL) data from Ireland has meant that the majority of these glacial isostatic adjustment (GIA) modelling studies of the British Isles region have tended to concentrate on reconstructing ice cover over Britain. However, the recent development of a sea-level database for Ireland along with emergence of new glaciological data on the spatial extent, thickness and deglacial chronology of the Irish Ice Sheet means it is now possible to revisit this region of the British Isles. Here, we employ these new data to constrain the evolution of the Irish Ice Sheet. We find that in order to reconcile differences between model predictions and RSL evidence, a thick, spatially extensive ice sheet of c. $600-700 \mathrm{~m}$ over much of north and central Ireland is required at the LGM with very rapid deglaciation after 21 000 cal. BP. 


\section{INTRODUCTION}

Recently, a number of researchers have modelled observations of glacio-isostatic adjustment (GIA) from the British Isles (e.g. Lambeck, 1991; Lambeck, 1993a; Lambeck, 1993b; Lambeck, 1995; Lambeck et al., 1996; Peltier et al., 2002; Shennan et al., 2002; Shennan et al., 2000c; Shennan et al., 2000d; Shennan et al., 2006a). These efforts have been facilitated by the availability of long time-series records of relative sea-level (RSL) change in Britain which, through the process of geophysical modelling, can be used to gather information regarding former ice extent, thickness and melting history, as well as viscosity structure within the mantle. However, in the past, the fragmentary nature of the Irish RSL record, allied with a paucity of observational constraints on the Irish Ice Sheet, has deterred researchers from using these data to constrain either the ice history or sub-surface viscosity structure for this region. Notable exceptions to this are the works by Lambeck (1996) and Lambeck \& Purcell (2001), which utilize existing records of RSL to constrain the vertical limits of the Irish Ice Sheet.

Since these publications, there have been a number of pertinent developments that mean it is now timely to re-evaluate the contribution Irish observational data can make to modelling GIA in the British Isles. Firstly, the body of available Irish sea-level data has grown since the work of Lambeck and co-workers. This is augmented by new, high resolution RSL records dating back to c. $16000 \mathrm{BP}$, from sites immediately adjacent to Ireland (Shennan et al., 2006b), which provide a powerful and unique constraint on model reconstructions of the Irish Ice Sheet.

Secondly, Brooks \& Edwards (2006) have developed a sea-level database for Ireland in which observations of RSL have been screened and classified according to established protocol for the analysis of sea-level data (e.g. Kidson \& Heyworth, 1979; Heyworth \& Kidson, 1982; Shennan, 1982; 1986; Shennan, 1989; Shennan \& Horton, 2002). This objective classification permits users of the database to readily identify the reliability of the available RSL information, and helps to discriminate potentially erroneous data. A similar database for the UK (Shennan \& Horton, 2002), has been integral to previous GIA modelling studies from Britain (e.g. Lambeck, 1995; Shennan et al., 2002; Shennan et al., 2006a). 
Thirdly, new data on the spatial extent (e.g. O'Cofaigh \& Evans, 2001; Hiemstra et al., 2006; Sejrup et al., 2005) and thickness (e.g. Rae et al., 2004; Bowen et al., 2002) of the Irish Ice Sheet since the Last Glacial Maximum (LGM) are now available. Furthermore, a number of Accelerator Mass Spectrometry (AMS) radiocarbon dates derived from marine muds have, for the first time, delivered chronological control on the post-LGM deglacial phase (e.g. McCabe \& Haynes, 1996; McCabe \& Clark, 1998, 2003; McCabe et al., 2005). In addition, field evidence now indicates that ice from the British Isles coalesced with Fennoscandian ice during the late Devensian (e.g. Sejrup et al., 1994, 2005; Svendsen et al., 2004; Carr et al., 2006), producing a more laterally extensive ice sheet than envisaged by Lambeck (1996).

Finally, Shennan et al. (2006a) have recently developed a revised GIA model for the British Isles (hereafter referred to as BIM-1), which satisfies key glaciological, seismic and sea-level constraints from both near- and far-field localities. This new model incorporates a more realistic assessment of ice sheet mass (and associated crustal loading) than previous studies by accounting for the effects of topography/bathymetry on ice thickness (Milne et al., 2006). Importantly, whilst this model has an Irish Ice Sheet component, it is not calibrated using any of the Irish RSL data. Consequently, the new dataset of Irish RSL reconstructions can provide a powerful, independent test of its earth and ice components.

In this paper, we evaluate the RSL predictions of BIM-1 against the independent Irish dataset. We demonstrate that significant misfits exist between observations and predictions for certain portions of the Irish coastline, indicating limitations in one or more components of BIM-1. We investigate the source of these limitations by examining the effects of modifying the Irish Ice Sheet and earth parameters of this model. In light of these results, we produce a revised model of the Irish Ice Sheet that satisfies both RSL and glaciological field constraints. Our results also indicate that minor modifications of the earth model are required to reconcile RSL predictions with observations from Ireland and the west coast of Britain. 
Author's Final Review Copy - TARA (http://www.tara.tcd.ie)

\section{Modelling Relative Sea-Level Change}

The use of geophysical models to simulate RSL change associated with the growth and ablation of mid-to-high latitude ice sheets is well established (e.g., Walcott, 1972; Peltier, 1974; Farrell \& Clark, 1976; Peltier \& Andrews, 1976; Nakada \& Lambeck, 1987; Mitrovica \& Peltier, 1991; Johnston, 1993; Milne \& Mitrovica, 1996; Milne et al., 1999). In essence, models of GIA consist of three key elements: an ice loading model (to define the global distribution of grounded ice thickness over time), an earth model (to simulate deformation of the solid earth to surface loading) and an algorithm to compute associated changes in sea level (which, as well as being a key observable, is also an important component of the GIA loading model).

Some authors have expressed concern about the ability of geophysical models to accurately reproduce patterns of RSL change (e.g. McCabe et al., 2005). It has been argued that models of this type are over-reliant on Holocene sea-level observations to constrain predictions of RSL change during the earlier deglacial phase (e.g. McCabe, 1997), whilst others have suggested that such models are unable to capture detailed variations in RSL change during the Holocene period (e.g. Smith, 2005). However, such criticisms are often based upon controvertible indicators of former sea-level which as yet cannot provide unequivocal data with which to test these suggestions.

This study tests and modifies the BIM-1 GIA model employed in Shennan et al. (2006a), the key components of which are outlined below.

\subsection{Earth Model}

The earth model employed in this investigation is a spherical, self-gravitating, compressible, Maxwell visco-elastic body. The elastic and density structure are taken from seismic constraints (Dziewonski \& Anderson 1981) and are depth-parameterised with a resolution of between 10 and $25 \mathrm{~km}$. The viscosity structure is more crudely parameterised into three layers which correspond to the lithosphere (in which the viscosity is set to a very high value of $1 \times 10^{43} \mathrm{~Pa} \mathrm{~s}$ ), the upper mantle (from the base of the lithosphere to the $670 \mathrm{~km}$ seismic discontinuity) and the lower mantle (from $670 \mathrm{~km}$ depth to the core-mantle boundary). 
In this study, we employ the same viscosity parameters that have resolved discrepancies between far-field RSL data and model predictions (Bassett et al., 2005) and delivered a good fit to the observational evidence of post-glacial RSL change in Britain (Shennan et al., 2006a). These values are 1) a lithospheric thickness of $71 \mathrm{~km}, 2)$ an upper mantle viscosity ( $\left.v_{u m}\right)$ of $5 x$ $\left.10^{20} \mathrm{~Pa} \mathrm{~s}, 3\right)$ a lower mantle viscosity $\left(\mathrm{V}_{\mathrm{LM}}\right)$ of $4 \times 10^{22} \mathrm{~Pa} \mathrm{~s}$.

\subsection{Sea-Level Model}

To generate sea-level predictions based on an input earth and ice model, we solve the most recent, generalised, form of the sea-level equation (Mitrovica \& Milne 2003; Kendall et al., 2005). By applying this most recent version of the theory, the influence of shoreline migration and sea-level changes in areas of ablating marine-based ice are accounted for. The theory we apply also takes into account the influence of GIA-induced perturbations in earth rotation on sea-level change (e.g. Milne \& Mitrovica 1996). All predictions were generated using a spherical harmonic truncation of degree and order 256.

\subsection{Ice Model}

The ice model we adopt is comprised of a relatively low resolution global model with a higher resolution model for the BIIS. The global component of the ice model is the same as that used by Shennan et al. (2006a) and follows the analyses of Bassett et al. (2005) which gives a close fit with far-field observations of RSL dating from the time of the LGM to c. 9000 BP. The Holocene component of this model remains to be calibrated and so in the following analyses we adopt the findings of Nakada \& Lambeck (1989) who suggest a late Holocene eustatic melt water contribution of c. $2 \mathrm{~m}$ between 6000 and 2000 BP.

In order to accurately model GIA observations from Ireland and adjacent regions, a highresolution spatial and temporal description of the local to regional ice load leading up to and following the LGM is required (Lambeck, 1993a). The space-time evolution of the Irish component of BIM-1 is illustrated in Figure 1. Overall advance and retreat phases are based on the findings of Sejrup et al. (1994, 2005), with extensive ice accumulation signalling the end of the Alesund Interstadial at c.33 $000 \mathrm{BP}$ and leading to coalescence of the British and Fennoscandian ice sheets. This configuration is interrupted by marked ice sheet retreat at 26 
000 and 25000 BP before rapid expansion of the BlIS around the time of the LGM. Deglaciation begins at $21000 \mathrm{BP}$, with the removal of ice from both Ireland and the UK largely complete by 15000 BP (e.g. Ballantyne, 1997).

\section{Reconstructing Relative Sea-Level Change}

Over thirty years of international research, coordinated under the auspices of a series of International Geoscience Programme (IGCP) projects, has produced a well-defined methodology for developing records of relative sea-level change from sedimentary coasts (Edwards, 2005). Central to this is the use of sea level index points which fix the past altitude of sea level in time and space (Tooley, 1978; Preuss, 1979; Van de Plassche, 1986). Detailed consideration of sea level index points and their associated error terms are given in a series of publications (e.g. Kidson \& Heyworth, 1979; Heyworth \& Kidson, 1982; Shennan, 1982; 1986; Horton et al., 2000). In brief, for a sample to be established as a sea level index point, it must possess information regarding its location (latitude and longitude), its altitude (relative to a levelling datum), its age (commonly inferred from radiocarbon dating), and its vertical relationship to a contemporaneous tide level (termed the indicative meaning).

Relative sea-level data from Ireland have recently been screened, classified and compiled into a database by Brooks \& Edwards (2006) (see Appendix 1 for contributors). All index points have location information (latitude / longitude in decimal degrees) that is accurate to within $1 \mathrm{~km}$. At present, lengthy suites of index points from single sites in Ireland are rare. Instead, SLIs are grouped into 21 distinct geographical regions to permit more meaningful comparison between RSL observations and predictions (see Table 1 and Figure 2). Most of the sea-level data have age information provided by radiocarbon dating, calibrated using CALIB 5.0.1 (Stuiver et al., 2005). Some of these dates are also corroborated via pollen chonostratigraphic data. The altitude of all index points is defined relative to OD (Belfast), a mean sea-level datum.

The RSL database classifies samples primarily on the quality of their indicative meaning. All 'Primary' SLIs have a quantified vertical relationship to a former tide level, associated with clearly defined error terms. In situations where the indicative meaning of a sample is less well quantified, data have been grouped into a 'Secondary' tier of index points. Where a dated 
sample has no discernable relationship with sea-level, or has formed outside of the tidal frame, samples are categorized as 'limiting dates', and provide a maximum (or minimum) limit for sea level at a given time. 'Primary' limiting dates include dated samples which are associated with a known environment (e.g. freshwater peat), whilst 'Secondary' limiting dates are derived from material whose source environment is unclear or contested. A number of AMS radiocarbon dates taken from foraminifera contained within 'glaciomarine muds' are included in this latter category.

Both types of data are useful for testing RSL predictions produced by GIA models, since sea-level curves should pass through SLIs and remain within the constraints imposed by limiting dates. Post-depositional compaction of the sediment column, either under its own weight or as a consequence of subsequent loading by water or an overlying sediment burden may lower the reconstructed altitude of former RSL. This will be greatest where index points are established from thick intercalated sedimentary sequences and consequently, when comparing predictions with observations from such sequences, best fit RSL predictions should lay towards the top of the SLI scatter (e.g. Shennan et al., 2002, 2006a).

\section{Testing the BIM-1 GIA MODEL FOR the BRITISH ISLES}

The BIM-1 GIA model is used to produce estimated RSL curves for a series of locations around the Irish coast and adjacent areas in western Britain. These curves are plotted in Figure 3 alongside the geologically-based RSL reconstructions. The model predictions along Ireland's east coast (Dublin (1) and S. Wexford (2)), south coast (E. Cork (4)) and west coast (Connemara (11)), are in reasonable agreement with the observational dataset. This indicates that, away from the former centre of loading by the Irish ice sheet, BIM-1 is effective in reproducing the dominant patterns of change. Further to the north and west, however, significant discrepancies begin to emerge between the model predictions and the empirical RSL data.

The first of these misfits is the tendency for BIM-1 to underestimate the maximum height of late Devensian RSL along the north Ulster coastline, as indicated by abundant raised shoreline evidence in this region. Limitations associated with dating and quantifying the indicative meaning of raised shorelines, coupled with the lack of primary index points for this 
time period, prevents a precise quantification of this discrepancy. Nevertheless, these shorelines provide strong evidence of higher sea-levels, both to the west and south of Antrim, than indicated by the model (Stephens and Synge, 1965; Synge and Stephens, 1966; Synge, 1977a, b; Mitchell, 1977). For example, in Derry (17), a late Glacial RSL of up to $+25 \mathrm{~m}$ (compared to a modelled estimate of c. $+13 \mathrm{~m}$ ) is suggested by Stephens \& Synge (1965), whilst in North Down (19), Stephens \& McCabe (1977) find evidence of raised shorelines at heights of $+30 \mathrm{~m}$ (compared to a modelled estimate of just over $+10 \mathrm{~m}$ ).

The second misfit concerns the presence of a Holocene high-stand (commonly around $6000 \mathrm{BP}$ ), where ongoing crustal rebound starts to outpace dwindling sea level rise. The model delivers predictions of Holocene RSL higher than present as far south and west as Sligo (13), as indicated by the $0 \mathrm{~m}$ isobase in figure 4 . In west Donegal (14), BIM-1 predicts $\mathrm{RSL}$ of approximately $+2 \mathrm{~m}$ at $6000 \mathrm{BP}$. Whilst there are very few locations in Ireland where the magnitude of the Holocene highstand can be tightly constrained (Brooks \& Edwards, 2006), the work of Shaw (1985), Shaw \& Carter (1994), Gehrels (2004) and Harmon (2006) in Donegal has enabled the spatial signature of the $0 \mathrm{~m}$ Holocene isobase to be reasonably well defined. The index point data provided by the authors above shows that RSL occupied a position around $-2 \mathrm{~m}$ at c.5000 BP in west Donegal (14) and suggests that the $0 \mathrm{~m}$ threshold lies somewhere along the north Donegal coastline (i.e. further to the north and east than suggested by BIM-1). On the Isle of Man (24), similar discrepancies exist with the Holocene RSL data. Here, the model predicts values in excess of $+5 \mathrm{~m}$ whereas the data constrain sea level to have been no more that $2 \mathrm{~m}$ above present during this period.

\section{Examining the Possible Causes of Poor Model Performance}

The RSL data from Ireland demonstrate that BIM-1 performs poorly in areas that have experienced the greatest loading from the Irish ice sheet, but that it can predict RSL change with reasonable accuracy in those areas that have experienced thinner, or shorter-duration ice cover. In light of this, we perform a series of analyses to examine the Irish Ice Sheet component of BIM-1 and its influence on the pattern and magnitude of predicted RSL change. 


\subsection{The role of the Irish Ice Sheet}

In order to predict the timing and magnitude of glacial rebound, it is necessary to know the size (thickness and lateral extent) of the ice sheet. In addition, it is important to understand when, how fast and by how much this size has changed through time. This choice of input parameters inevitably means that there is a degree of model solution non-uniqueness due to the trade-off between variables, and this is a recognised limitation inherent in GIA modelling studies (e.g. Mitrovica \& Peltier, 1995). However, both the observational RSL data and glaciological field evidence (below) provide a stringent set of independent conditions that must be met, and any adjustment to the nominal BIM-1 ice sheet model are made in light of these constraints.

Ireland (along with Britain) is thought to have been ice free during the Derryvree cold phase, in agreement with a radiocarbon date of c.34 $000 \mathrm{BP}$ derived from organic silts in northwest Ireland (Colhoun et al., 1972). This warm episode was abruptly terminated by rapid ice sheet growth and expansion which lasted until c.27 000 BP. Before the onset of the LGM in this region at $24000 \mathrm{BP}$, a brief retreat phase of the BIIS ensued between 26000 and 25 000 BP in agreement with the inferences of Serjup et al. (1994).

During the LGM, a laterally extensive ice sheet is believed to have existed over much of Ireland and out onto the adjacent shelf region (e.g. Evans et al., 1980; Warren, 1992; McCabe, 1995; Clark and Meehan, 2001; Serjup et al., 2005). To the south, ice is now considered to have extended beyond the traditional South of Ireland End Moraine (SIEM) limit (O'Cofaigh \& Evans, 2001; Evans \& O'Cofaigh, 2003; Hegarty, 2004; Ballantyne et al., 2006). Recent evidence also indicates ice extending out into the Celtic Sea south of the Isles of Scilly (Scourse et al., 1990; Scourse, 1991; Hiemstra et al., 2006). In terms of ice thickness, there is a relative paucity of constraints provided by trimline data within Ireland when compared to the UK (e.g. Ballantyne et al., 1998a, b; McCarroll \& Ballantyne, 2000). In the south west of Ireland (Macgillycuddy's Reeks), Rae et al. (2004) use trimline evidence to infer an ice sheet thickness of c.370m whilst in the east (Wicklow Mountains), Ballantyne et al. (2006) employ similar evidence to suggest that only peaks above c.725m remained ice free at the LGM. Elsewhere, the evidence is more equivocal: In the north of Ireland, ice is believed to 
have reached a thickness of at least $750 \mathrm{~m}$ (after terrain correction) (e.g. Clark \& Meehan, 2001; McCabe, 1997) although thicknesses are suggested to be somewhat less further south since the highest peaks of the Knockmealdown mountains (Lewis, 1976), Galtee mountains (McCabe, 1985) and Connemara mountains (Coudé, 1977) are proposed to have been nunataks at the LGM.

In BIM- 1, the onset of deglaciation begins after 21000 BP with (rapid) ice retreat taking place up until 19000 BP. By this time, the Irish Midlands are suggested to have been ice free, and the ice margin in the Irish Sea occupied a position to the north of the Isle of Man. Interrupting this ice retreat from the LGM was a large-scale ice re-advance which affected much of the country (e.g. McCabe et al. 1998; McCabe \& Clark, 2003; McCabe et al., 2005). This 'Killard Point' or 'Heinrich 1' event involved ice re-advance as far south as the Shannon estuary and the north of the Isle of Man in the Irish Sea Basin (Thomas et al., 2004). This event was brief however, and ice retreat followed shortly after, with the region becoming ice free by 15000 BP (e.g. McCabe et al., 2005). During the Younger-Dryas event (c.13 000 BP) ice was confined to mountain cirque glaciation (Murray-Gray \& Coxon, 1991; Coxon, 1997) and was on a significantly smaller scale than its equivalent in the Scottish Highlands (e.g. Thorp, 1986).

The underestimation of maximal late Devensian RSL by BIM-1 indicates the need for greater crustal depression at this time. This requires either an earlier, or larger LGM ice build up, and/or a more persistent ice sheet during deglaciation (e.g. slower melting). In contrast, the overestimation of the Holocene high-stand around $6000 \mathrm{BP}$ indicates that the model predicts too much glacial rebound by this time. This requires a reduction in LGM ice volume and/or persistence accompanied by more rapid melting during the deglacial phase. The latter therefore places clear constraints on the modifications acceptable to produce the required late Devensian RSLs.

\subsubsection{Sensitivity analysis}

In order to demonstrate the effects of varying ice volume at the time of the LGM and during the deglacial phase, we begin by presenting two sets of sensitivity analyses conducted using BIM-1 but with differing modifications to the Irish Ice Sheet component. In the past, 
researchers working outside the GIA modelling community have sometimes expressed concern at the accuracy of GIA ice model components at the local scale and the impact these inaccuracies may have on predictions of RSL (e.g. McCabe, 1997; McCabe et al., 2005). For this reason, we first examine the influence of local-scale ice movements, such as the readvance associated with the 'Killard Point' stadial included in the nominal ice model for BIM-1. We do this by considering the contrasting RSL changes that arise if Ireland were completely ice-free after $19000 \mathrm{BP}$ (Model A). We also consider a second model (Model B) in which the spatial extent of Irish ice to the west and north-west of Ireland at the time of the LGM is reduced, with (onshore) ice limits similar to those proposed by Stephens \& Synge (1965), and Bowen et al. (2002).

The results of these two experiments are plotted in Figure 3 alongside the original RSL predictions of BIM-1. It is clear from this that in the south and southwest of Ireland (away from the centre of crustal loading), the effects of removing all ice from Ireland after $19000 \mathrm{BP}$ (Model A) are small. However, in the north of Ireland the changes are more pronounced. The greatest divergence from the nominal BIM-1 ice model occur at c. $15000 \mathrm{BP}$ with a reduction in RSL predictions of c.10-12m. During the Holocene there is also an appreciable difference between BIM-1 and Model A predictions, with the latter commonly reducing the amplitude of the Holocene highstand by c. 2-3m. The greatest difference between BIM-1 predictions and the RSL predictions from Model B (removal of west coast ice at the LGM) occurs, perhaps unsurprisingly, at sites located in NW Ireland. However, even in west Donegal (14), where the largest change in RSL is experienced, the effect of total offshore ice removal only contributes to c. $5-6 \mathrm{~m}$ of RSL lowering at 20 000BP. At all sites, the influence on the Holocene GIA signature is not significant.

\section{5:1:2 Improving the fit with empirical RSL evidence}

The results of these sensitivity analyses clearly demonstrate the requirement for a very thin ice sheet during the deglacial phase, since significant reductions in the amplitude of the Holocene high stand (and the associated geographical location of the Holocene 0m isobase) cannot be generated by local-scale changes in LGM ice thickness alone (Model B). Whilst the 
results from Model A significantly improve the fit with Holocene RSL evidence, the position of the Holocene $0 \mathrm{~m}$ isobase in Donegal is still too far to the west.

We perform a further set of analyses to examine the effects of changing the duration of ice loading, initiating deglaciation shortly after 22000 BP (e.g. McCabe et al., 2005) as opposed to after 21000 BP in BIM-1. In the first analysis (Model C), we adopt the same pre-LGM and LGM ice sheet as BIM- 1 and, in accordance with the earlier sensitivity analyses, adopt a very thin Irish Ice Sheet of approximately half the ice thickness of BIM-1 during the deglacial phase. The second analysis (Model D) is identical to Model C except that, at the time of the LGM, we invoke a more laterally extensive ice sheet of similar morphology to that proposed by Sejrup et al. (2005). In this model, offshore ice thicknesses approach c. 650m off NW Donegal with ice extending out to the continental shelf break. Ice thickness in the northern Irish Sea Basin are also increased to a similar thickness in order to reconcile glaciological evidence suggesting that Snaefell $(621 \mathrm{~m})$ on the Isle of Man was transgressed by ice at the LGM (e.g. Bowen, 1973; Boulton et al., 1977).

Figure 5 shows a comparison between RSL predictions generated by the nominal ice model for BIM-1 and the revised ice models C and D. Once again, away from the centre of ice loading over the north of Ireland, the disparity between RSL predictions from the three models becomes insignificant. However, around the north of Ireland coastline the differences become more apparent. Predictions from Model C deliver a far better fit with the Holocene observational RSL data than BIM- 1 and the Holocene $0 \mathrm{~m}$ isobase no longer lies to the west of Sligo. A brief comparison between Model C and Model A (all Irish ice removed from BIM -1 after $19000 \mathrm{BP}$ ) reveals that after c. $15000 \mathrm{BP}$, predictions from the two models are largely identical with differences in the Holocene of no more than a few decimetres.

The RSL predictions produced by Model D (laterally extensive, thicker LGM ice) show even greater agreement with RSL data. The geographical extent of the Holocene high stand in the north is restricted, whilst concomitantly increasing maximal late Devensian RSL predictions to heights above those delivered by Model C. However, even this increase is insufficient to satisfy the geomorphological RSL evidence and limiting data (minimum) provided by dated 'glaciomarine' muds from around the north and eastern Ulster coastline. Neither do predictions from Model D yield a particular good fit with the high resolution sea-level index 
point data from Islay (22) and Knapdale (23) in southeast Scotland. In fact, in the north of Ireland, maximal late Devensian RSL predictions derived from this ice model are no higher than those produced by BIM- 1 since the increase in RSL predictions induced by thicker ice is offset by the effects of rapid and earlier deglaciation.

\subsubsection{A best-fit Irish Ice Model}

The analyses conducted in section 5:1:2 demonstrate that whilst changes to the ice sheet in the deglacial phase have greatly improved the fit with the Holocene observational evidence, significant misfits remain between model predictions and geomorphological RSL evidence from the late Devensian. Specifically, the maximal predictions of late Devensian RSL are consistently below the geomorphological evidence of RSL for this time period. Because of this, it would appear that early deglaciation shortly after $22000 \mathrm{BP}$ is incompatible with the Irish RSL data. In light of these results, we develop a revised Irish Ice Sheet component for BIM-1 that is constrained by both glaciological and RSL data (Model E, Figure 6). This model uses the same pre LGM ice build up, and LGM duration (24 $000-21000 \mathrm{BP}$ ) as the nominal Irish Ice component of BIM-1. Our best fit model differs from BIM-1 by having thicker ice in the Irish Sea and to the northwest of Ireland at the LGM (similar to Model D). We also have thickened ice across the Wicklow Mountains, Irish Midlands and over Kerry, in accordance with the trimline data of Rae et al. (2004) and Ballantyne et al. (2006). During the deglacial phase (20 000 to $16000 \mathrm{BP}$ ), we adopt an almost identical ice sheet to that described in Model C, including rapid onset of deglaciation at 21000 BP (figures 6 and 7).

Despite significant differences between the Irish Ice Sheet component of the nominal BIM-1 model and our revised 'best fit' ice model (Model E), there are no discernible differences between the RSL predictions of the two models for the majority of sites along Ireland's east, south and west coasts (see figure 8). The only exception to this is in Dublin (1), where the significantly greater volume of ice in the Irish Sea Basin associated with Model E results in more crustal uplift and higher predicted Holocene RSLs. Similarly, for most sites along the western coast of Britain, there is good agreement between RSL predictions from the two models. 
Model E also produces a greatly improved fit with RSL data from the north of Ireland. The problematic Holocene high stand from Sligo (13) no longer exists and is greatly lowered in west Donegal (14). At all sites along the Ulster coastline, RSL predictions from Model E now yield a far better fit with the limiting data (maximum) in both the Holocene and back into the late Devensian. This is achieved whilst also generating sufficient crustal depression to satisfy most of the raised shoreline data and a lot of the limiting data (minimum) from the AMS radiocarbon dated 'glaciomarine' muds.

Kelley et al. (2006) have recently uncovered new evidence for the depth of the Lateglacial sea level lowstand in Belfast Lough (region 19) based on a submerged 'beach' deposit at c. $30 \mathrm{~m}$ below present sea level. AMS radiocarbon dates obtained from an 'inter-tidal' shell assemblage contained within the deposit return ages of c.13 $400 \mathrm{BP}$ although at this time, reconstructions of RSL associated with Model $E$ are around $-5 m$ below present (Figure 8). The work of Kelley et al. (2006) suggests that model E underestimates the amount of isostatic rebound that has taken place since the onset of deglaciation although reference to figure 3 demonstrates that this discrepancy cannot be overcome through reducing ice thickness during the deglacial phase. It is worth noting however, that whilst the lithostratigraphic units described by Kelley and co workers appear consistent with the characteristics of beach material, the depositional setting cannot be established with certainty. Furthermore, it is hard to assess whether the dates obtained for this submerged shoreline were derived from in situ material and as such, this data cannot be regarded as robust evidence for the former position of sea level.

It is apparent that at both Islay (22) and Knapdale (23), the fit with the index point data is not as good as with BIM-1. This misfit is caused by our thin Irish Ice Sheet during the deglacial phase which has enabled increased crustal rebound to occur and a subsequent lowering of RSL. However, local scale adjustments in both Scottish ice thickness and more specifically the rate of ice retreat should provide a solution to these model misfits. 


\subsection{The Role of the Earth Model}

The Earth model used in these analyses (and outlined in section 2:1) is parameterised into three layers which correspond to the lithosphere, the upper mantle and the lower mantle. When considering patterns of GIA in regions once occupied by small ice sheets such as the BIIS, changes in the depth/viscosity of the lithosphere and upper mantle are of greatest significance. Adjustments to the lower mantle would appear less important since even the rebound associated with the much larger Fennoscandian Ice Sheet is only weakly sensitive to this model parameter (Mitrovica and Peltier, 1991; Peltier, 1996).

Lithospheric thickness controls the magnitude of crustal depression in response to loading and any changes to this will either uniformly raise or lower predictions of RSL throughout the entire post glacial period. It follows that changes in the depth of the lithosphere will be unable to reconcile differences between predictions from BIM-1 and the RSL evidence since maximal predictions from BIM- 1 are generally too low in the late Devensian and too high in the Holocene. However, upper mantle viscosity is of more relevance here since this parameter controls the rate of crustal response to loading-unloading episodes (e.g. Lambeck, 1993a,b). Estimates for upper mantle viscosity have been consistent between various modelling studies from the British Isles with most workers preferring either a value of $4 \times 10^{20} \mathrm{~Pa}{ }^{14} \mathrm{Cs}$ (Lambeck, 1993a; Lambeck, 1993b; Lambeck, 1995; Lambeck et al., 1996; Shennan et al., 2000c) or $5 \times 10^{20}$ Pa s (Peltier, 1998; Peltier, 2004; Peltier et al., 2002; Shennan et al., 2006a). Reducing the values of upper mantle viscosity will increase the response rate of the crust to loading and unloading episodes. The corollary of this will be a reduction in the rate of crustal deformation during the Holocene and consequently induce a lowering of RSL predictions during this period.

To examine the impact of changes in upper mantle viscosity, we perform a final set of sensitivity analyses on BIM-1 by producing RSL predictions generated with reduced upper mantle viscosity values of $3 \times 10^{20} \mathrm{~Pa} \mathrm{~s}$ and $4 \times 10^{20} \mathrm{~Pa}$. These are compared with the original RSL predictions from BIM-1 ( $\left.\mathrm{V}_{\mathrm{UM}} 5 \times 10^{20} \mathrm{~Pa} \mathrm{~s}\right)$ and the results presented in figure 9. In the south and west of Ireland, where the eustatic contribution to RSL change appears to dominate over the glacio-isostatic component, the reduction in upper mantle viscosity has 
negligible impact on the RSL predictions. However, toward the centre of loading in the north the impact of these changes becomes far more apparent. At all sites around the Ulster coastline, reduced upper mantle viscosity raises maximal predictions of RSL by, in the case of the $\mathrm{V}_{\mathrm{UM}} 3 \times 10^{20} \mathrm{~Pa}$ s model, in excess of $10 \mathrm{~m}$. Conversely, the magnitude (and geographical range) of the Holocene highstand is reduced: In west Donegal (14) it is lowered by c.2m by adopting the $\mathrm{v}_{\mathrm{UM}} 4 \times 10^{20} \mathrm{~Pa} \mathrm{~s}$ model, whilst the $\mathrm{v}_{\mathrm{UM}} 3 \times 10^{20} \mathrm{~Pa} \mathrm{~s}$ model has the effect of removing the highstand altogether. In fact, when adopting the low viscosity $\left(\mathrm{V}_{\mathrm{um}} 3 \times 10^{20} \mathrm{~Pa}\right.$ s) Earth model, the greatest magnitude of Holocene highstand in Ireland is no more than $+2.5 \mathrm{~m}$.

Finally, we consider the effects of running our best fit model (Model E) with a lower upper mantle viscosity Earth model of $4 \times 10^{22} \mathrm{~Pa}$ s. Reference to figures 10 and 11 shows that this combination of a thin Irish ice sheet during the deglacial phase coupled with a reduced upper mantle Earth model does yield a close fit with the empirical RSL data. The Holocene highstand is removed from west Donegal (14) and model predictions are now in good agreement with the index point data from this locality. In north Antrim (18) (where the isostatic component of the RSL signal is at its greatest) the Holocene highstand is c. $+5 \mathrm{~m}$. This figure is significantly lower than the $\mathrm{c} .+8 \mathrm{~m}$ highstand predicted by running BIM- 1 with an earth model of $\mathrm{V}_{\mathrm{UM}} 5 \times 10^{20} \mathrm{~Pa} \mathrm{~s}$ (as in the original Shennan et al., analyses). Elsewhere around the Ulster coastline, model predictions satisfy all the constraints placed by the primary limiting date evidence as well as a large number of the secondary limiting dates.

\section{Discussion}

The analyses undertaken in section 5 outlines the extent to which model predictions of RSL respond to adjustments in both ice and Earth model input parameters. Significant improvements in the fit between BIM- 1 predictions and the Irish RSL data can be achieved through altering the Irish component of this regional ice model yet changes in the ice model alone have not completely reconciled discrepancies with observations of RSL. In particular, we are still left with a Holocene highstand in west Donegal which is unsubstantiated by field evidence. Interestingly, a similar problem relating to the position of the $0 \mathrm{~m}$ Holocene isobase on the west coast of Britain has been encountered in recent modelling studies of the British 
data (Shennan et al., 2002; Shennan et al., 2006a) and, as in the case of this investigation, a solution could not be found through adjustments in the regional ice model. Model predictions of the geographical location of the $0 \mathrm{~m}$ isobase can be marginally improved through increasing the eustatic melt water contribution since 7000 BP to a maximum of 3m (e.g. Lambeck, 2002). However, we are still left with predictions of a Holocene high stand in both west Donegal and north Wales which are at odds with available field evidence.

Both Milne et al. (2006) and Shennan et al. (2006a) have shown that predictions of RSL in the post glacial are sensitive to ice sheet evolution in the pre-LGM period. For this reason, changes in the ice sheet thickness were considered during the temporary retreat phase (25 $000-26000$ BP). However, removing this retreat stage only imparted a very minor GIA signal after the LGM. Because no further changes can be made to the Irish ice model without contradicting the empirical glaciological evidence, it would appear that the Earth model employed in the Shennan et al. (2006a) analyses is untenable with the Irish RSL evidence.

Significant alterations to BIM- 1 RSL predictions can also be achieved through lowering the upper mantle viscosity of the Earth model. A greatly improved fit between BIM- 1 predictions and the Irish RSL dataset is achieved by adopting an upper mantle viscosity of $4 \mathrm{x}$ $10^{20} \mathrm{~Pa} \mathrm{~s}$ which is a similar value to that used by Lambeck and co workers in their earlier analyses from the region. However, the problematic Holocene high stand remains in west Donegal. Whilst this may be removed by lowering the upper mantle viscosity still further to a value of $3 \times 10^{20} \mathrm{~Pa} \mathrm{~s}$, the overall fit with available RSL data from the north of Ireland becomes extremely poor: The greatest Holocene highstand around the Ulster coastline is no more than $2.5 \mathrm{~m}$ and the RSL predictions become significantly at odds with the Holocene index point data from south Down (20) and south west Scotland. In order to reconcile the differences between the BIM-1 ( $\mathrm{V}_{\mathrm{UM}} 3 \times 10^{20} \mathrm{~Pa}$ s) and the Holocene RSL data, a substantial increase in crustal loading would be required during a large part of the late Devensian. However, the resultant rise in RSL in the late Devensian time interval would almost certainly be at odds with available geomorphological evidence of RSL from Ireland. Similarly, it is hard 
to see how such a low viscosity upper mantle Earth model would be compatible with the long time-series records of RSL change from the west coast of Scotland, particularly since trimline evidence provides a strict upper bound for the maximum thickness of ice at the time of the LGM. Because of the above, such a low viscosity upper mantle is extremely unlikely to provide an acceptable solution.

The above demonstrates that a resolution for model misfits cannot be achieved through changes to one or the other of the ice/Earth model. Instead, it is evident that combined revisions to both the existing BIM- 1 ice model and the original Earth model are desirable in order to achieve a solution that satisfies the constraints provided by both the RSL and glaciological evidence from Ireland. Indeed, running our best fit ice model (Model E) with a slightly reduced upper mantle viscosity of $4 \times 10^{20} \mathrm{~Pa} \mathrm{~s}$ would appear to provide a very good overall solution. Using this ice-Earth model combination satisfies nearly all the late Devensian RSL evidence from around the Ulster coastline and in Donegal, the predicted Om isobase now occupies the same geographical location as that reconstructed through field evidence (figure 11). On the Isle of Man and in North Wales, the fit with the Holocene data is considerably improved. Importantly, the well constrained 0m Holocene isobase on the east coast of Britain is largely unaffected by the revision to the Earth model.

An important, additional test of this revised Earth-ice model solution is the quality of the fit to the long time-series RSL records from Scotland (see figure 10). On first inspection, it appears as though the new reduced viscosity model is incompatible with the index point data from both Islay and Knapdale. However, whilst BIM- 1 is constrained by glaciological evidence, it is also inferred on the basis of the Earth model employed in the Shennan et al. (2002) investigation. Significantly, the analyses of Shennan et al. (2006a) has shown that the $96 \mathrm{~km}$ lithosphere used in the Shennan et al. (2002) paper is untenable with observational RSL data from Britain. This means that there now exists considerable scope to make local scale adjustments in the British Ice model, specifically in areas which are poorly constrained by trimline data. This will be addressed in a future paper that will consider GIA model fits to the entire UK and Irish RSL data as well as observations of present-day crustal motions derived from Global Positioning System (GPS) measurements. 


\section{Conclusion}

Observations of post-glacial RSL around Ireland are limited in both time and space and are generally less complete than records found in Britain. However, we have shown that the newly compiled and quality assessed Irish RSL database (Brooks \& Edwards, 2006) does provide an important data set with which to test GIA models for Ireland and the UK. Assuming that the influence of lateral earth structure beneath the British Isles produces a minor impact on predictions of RSL in this region, we conclude that the Irish Ice Sheet depicted in Shennan et al. (2006a) is wholly incompatible with observations of late Devensian and Holocene RSL in Ireland. Employing the same Earth model as Shennan et al., our 'best fit' ice model for Ireland comprises a thick, spatially extensive Irish ice sheet of around $700 \mathrm{~m}$ over much of north and central Ireland at the LGM. Relatively thick ice out to the continental shelf off the west coast of Scotland and Ireland coupled with thick Irish Sea Ice is required to produce a sufficient fit with observational RSL data from the late Devensian.

We find that predictions of RSL are sensitive to the specific rate and timing of deglaciation prior to the LGM. The Irish RSL data strongly favour very rapid deglaciation after $21000 \mathrm{BP}$ : Early (pre $21000 \mathrm{BP}$ ) deglaciation produces unacceptably low predictions of maximum late Devensian RSL in the north of Ireland and SW Scotland whilst gradual deglaciation between 20000 to 16000 BP deteriorates the fit with observations of Holocene RSL.

This study cannot offer unequivocal evidence for or against rejecting the South of Ireland End Moraine as the southerly limit of late Devensian Irish Ice. However, in order to fit the RSL data, a significant thickness of ice (c.500m) is needed over the Irish Midlands, which are only a short distance to the north of the South of Ireland End Moraine. If the moraine is taken as the true southern limit of LGM ice extent, it follows that the ice sheet would have had a very steep southern margin and this may be glaciologically implausible. 
Significantly, all of the models considered in the analyses presented here deliver maximal predictions of late Devensian RSL along Ireland's west coast that are well below present msl. No evidence is found in support of the suggestion by McCabe (2005); McCabe et al. (1986; 2005); Thomas and Chiverrell (2006) of higher than present late Devensian RSL along this stretch of coastline.

Only a limited fit with available records of RSL can be obtained by altering the Irish Ice Sheet component of BIM-1. Significant discrepancies with RSL data could not be resolved, particularly those in relation to the geographical position of the $0 \mathrm{~m}$ Holocene isobase. However, it was possible to solve this problem by making a minor reduction to the value of upper mantle viscosity employed in the Earth model. Despite the significant changes in RSL predictions bought about through making this adjustment to the Earth model, our results still conclusively demonstrate that the Irish component of BIM-1 is not compatible with the RSL data. The primary conclusion from our ice modelling - the need for a thinner Irish Ice Sheet soon after the LGM and throughout the deglacial phase - remains a robust requirement of the RSL data regardless of the adopted viscosity model.

Appendix 1

RSL Data Contributors

Battarbee RW, Scaife RG, Phetheon SJ. 1982. Palaeoecological evidence for sea-level change in the Bann Estuary in early Mesolithic. In Excavations at Mountsandel, Woodman (ed). HMSO 8pp.

Bedlington DJ. 1993. Holocene sea-level changes and crustal movements in North Wales and Wirral. Unpublished PhD thesis, University of Durham: Durham.

Birks HJB. 1982. Mid-flandrian forest history of Roudsea Wood National Nature Reserve, Cumbria. New Phytologist 90: 339-354.

Burenhuit G. 1980. The archaeological excavation at Carrowmore, Co. Sligo: Excavation seasons 1977-1979. Theses and papers in North European Archaeology 9: 142pp. 
Buzer JS. 1980. Pollen analysis of sediments from Lough Ine and Ballyally Lough, Co. Cork, Ireland. New Phytologist 86: 93-108.

Carter RWG. 1975a. Recent changes in the coastal geomorphology of the Magilligan Foreland, Co. Londonderry. Proceedings of the Royal Irish Academy 75B: 469-497.

Carter RWG. 1982a. Sea-level changes in Northern Ireland. Proceedings of the Geologists Association, London 93: 7-23.

Carter RWG, Orford JD. 1982. The south and east coasts of Co. Wexford: Irish Association for Quaternary Studies (IQUA) Field Guide no.4. IQUA; Dublin.

Carter RWG, Devoy RJN, Shaw J. 1989a. Late Holocene sea levels in Ireland. Journal of Quaternary Science 4(1): 7-24.

Carter RWG, Wilson P. 1990. Portstewart Strand and the Bann Estuary. In North Antrim and Londonderry: Irish Association for Quaternary Studies (IQUA) Field Guide no.13, Wilson $\mathrm{P}$ (ed). IQUA: Dublin; 18-23.

Colhoun EA, Ryder AT, Stephens N. 1973. ${ }^{14} \mathrm{C}$ age of an oak-hazel forest bed at Drumskellan, Co. Donegal and its relations to the late-Midlandian and Littletonian raised beaches. Irish Naturalists Journal 17: 321-327.

Devoy RJN, Delaney C, Carter RWG, Jennings SC. 1996. Coastal stratigraphies as indicators of environmental changes upon European Atlantic coasts in the late Holocene. Journal of Coastal Research 12: 564-588.

Devoy RJN, Nichol SL, Sinnott AM. 2004. Holocene sea-level and sedimentary changes on the south coast of Ireland. Journal of Coastal Research 39: (special issue)

Donner J, Jungner H. 1980. Radiocarbon ages of shells in Holocene marine deposits. Radiocarbon 22: 556-561.

Dresser PQ. 1980. Dublin radiocarbon dates III. Radiocarbon 22: 1028-1030.

Dresser PQ, Smith AG, Pearson GW. 1973. Radiocarbon dating of the raised beach at Woodgrange, Co. Down. Proceedings of the Royal Irish Academy 73B: 53-56.

Gaulin C, Delibrais G, Denèfle M. 1983. Analyse pollinique et detation par le ${ }^{14} \mathrm{C}$ d'une tourbiere submergée de l'age de Bronze dans le Nord-Ouest de I'Lande (presqu'île de Termon. Dungloe, Comte Donegal). Comptes Rendus de l'Académie des Sciences Paris 296: II, 305-307.

Gehrels R. 2004. Saltmarsh fieldwork, stratigraphy, micropalaeontology, transfer functions: Ireland. In Late Holocene Shallow Marine Environments Of Europe (HOLSMEER) final Report, Scourse J (ed). 107-120. 
Harkness DD, Wilson HE. 1979. Scottish Universities Research and Reactor Centre radiocarbon measurements III. Radiocarbon 21: 203-256.

Harmon M. 2006. Saltmarsh Archives of Relative Sea-Level Change During the Late Holocene in the North of Ireland. Unpublished PhD thesis, Queens University: Belfast.

Healy MG. 1995. The lithostratigraphy and biostratigraphy of a holocene coastal sediment sequence in Marazion Marsh, west Cornwall, U.K. with reference to relative sea-level movements. Marine Geology 124: 237-252.

Heyworth A, Kidson C. 1982. Sea-level changes in southwest England and Wales, Proceedings of the Geologists' Association 93: 91-111.

Harris CR. 1979a. Flandrian sediments and microfauna in Dublin Bay, Ireland. Unpublished PhD thesis. University of Dublin (TCD).

Hubbs CL, Bien GS, Suess HE. 1965. Radiocarbon 7: 66.

Huddart D. 1992. Coastal environmental changes and morphostratigraphy in southwest Lancashire, England, Proceedings of the Geologists' Association 103: 217-236.

Jessen K. 1949. Studies in late Quaternary deposits and flora history of Ireland. Proceedings of the Royal Irish Academy 52B: 85-290.

Kelley JT, Cooper JAG, Jackson DWT, Belknap DF, Quinn RJ. 2006. Sea-level change and inner shelf stratigraphy off Northern Ireland. Marine Geology 232(1-2): 1-15

Kidson C, Heyworth A. 1982. Sea-level changes in southwest England and Wales. Proceedings of the Geologists' Association 93: 91-112.

Liversage GD. 1968. Excavations at Dalkey Island, Co. Dublin, 1956-1959. Proceedings of the Royal Irish Academy 66C: 53-223.

Maloney BK. 1985. A Palaeoecological investigation of the Holocene back-barrier environment near Carnsore Point, Co. Wexford. Proceedings of the Royal Irish Academy 85B: 73-89.

Manning PI, Robbie JA, Wilson HE. 1970. The geology of Belfast and the Lagan Valley. Memoirs of the Geological Survey Northern Ireland.

McCabe AM, Haynes JR, Macmillan NF. 1986. Late-Pleistocene tidewater glaciers and glaciomarine sequences from north County Mayo, Republic of Ireland. Journal of Quaternary Science 1: 73-84. 
McCabe AM, Haynes JR. 1996. A late Pleistocene intertidal boulder pavement from an isostatically emergent coast, Dundalk Bay, eastern Ireland. Earth Surface Processes and Landforms 21: 555-572.

McCabe AM, Clark PU. 1998. Ice sheet variability around the North Atlantic Ocean during the last deglaciation. Nature 392: 373-377.

McCabe AM, Clark PU. 2003. Deglacial chronology from County Donegal, Ireland: implications for deglaciation of the British-Irish ice sheet. Journal of the Geological Society of London 160: 847-855.

McCabe AM, Clark PU, Clark C. 2005. AMS 14C dating of deglacial events in the Irish Sea Basin and other sectors of the British-Irish ice sheet. Quaternary Science Reviews 24: 1673-1690.

Mitchell GF. 1971. The Larnian culture: A minimal view. Proceedings of the Prehistoric Society 38: 274-283.

Mitchell GF. 1976. The Irish Landscape. Collins: London.

Mitchell GF. 1977. Raised Beaches and Sea Levels. In British Quaternary Studies-recent advances, Shotton FW (ed). Clarendon Press: Oxford; 169-186.

Mitchell GF. 1981b. The Littletonian warm stage - post 10,000 BP. In A Geology of Ireland, Holland $\mathrm{CH}$ (ed). Scottish University Press: Edinburgh; 235-238.

Mitchell GF, Stephens N. 1974. Is there evidence for a Holocene sea-level higher than that of today on the coasts of Ireland? Coll. Int. CNRS 219: 115-125

Morrison MES, Stephens N. 1961. Stratigraphy and pollen analysis of the raised beach deposits at Ballyhalbert, Co. Down. New Phytologist 59: 153-162.

Morrison MES, Stephens N. 1965. A submerged Late Quaternary deposit at Roddans Port on the northeast Coast of Ireland. Philosophical Transactions of the Royal Society, London 249B: 221-255.

Naylor D. 1965. Pleistocene and Post-Pleistocene sediments in Dublin Bay. Scientific Proceedinsg of the Royal Dublin Society Series A 2: 175-188.

O'Connell M. 1988. Streamstown Bay - partially submerged peat as evidence for later post-glacial sea-level change. In Connemara: Irish Association for Quaternary Studies (IQUA) Field Guide no. 11, O'Connell M, Warren WP (eds). IQUA: Dublin; 45-49.

Orford JD, Carter RWG. 1982b. Geomorphological changes on the barrier coast of south Wexford. Irish Geography 15: 70-84.

O'Sullivan A. 2001. Foragers, farmers and fishers in a coastal landscape: An intertidal archaeological survey of the Shannon estuary. Royal Irish Academy: Dublin.

Pearson GW. 1979. Belfast radiocarbon dates IX. Radiocarbon 21: 274-290. 
Pearson GW, Pilcher JR. 1975. Belfast radiocarbon dates VIII. Radiocarbon 17: 226-238.

Penney D. 1983. Post Glacial sediments and foraminifera at Dundalk, Ireland. Unpublished PhD Thesis, University of Dublin (TCD).

Prior DB. 1966. Late glacial and post-glacial shorelines in north-east Antrim. Irish Geography 5: 173-187.

Prior DB, Holland S, Cruickshank MM. 1981. A preliminary report on late Devensian and early Flandrian deposits at Carnlough, Co. Antrim. Irish Geography 14: 75-84.

Roberts DH, Chiverrell RC, Innes JB, Horton BP, Brooks AJ, Thomas GSP, Turner S, Gonzalez S. 2006. Holocene sea levels, Last Glacial Maximum deglacial environments and geophysical models in the northern Irish Sea Basin, UK. Marine Geology 231: 113-128.

Shaw J. 1985. Holocene coastal evolution, Co. Donegal, Ireland. Unpublished PhD Thesis, The University of Ulster: Coleraine.

Shaw J, Carter RWG. 1994. Coastal peats from northwest Ireland: implications for Late Holocene RSL change and shoreline evolution. Boreas 23: 74-91.

Shennan I, Hamilton S, Hillier C, Hunter A, Woodall R, Bradley S, Milne G, Brooks A, Bassett S. 2006b. Relative sea-level observations in western Scotland since the last glacial maximum for testing models of glacial isostatic land movements and ice-sheet reconstructions. Journal of Quaternary Science 21(6): 601-613.

Singh G, Smith AG. 1973. Post Glacial vegetational history and relative land and sea level changes in Lecale, Co. Down. Proceedings of the Royal Irish Academy 73B: 1-51.

Sinnott A. 1999. Holocene Sea-Level Changes From the South and Southeast Coasts of Ireland. Unpublished PhD Thesis, University College Cork.

Smith AG, Pilcher JR. 1973. Radiocarbon dates and vegetational history of the British Isles. New Phytologist 72: 903-914.

Smith AG, Pearson GW, Pilcher JR. 1974. Belfast radiocarbon dates VII, Radiocarbon 16: $269-276$.

Stephens N, Collins AEP. 1960. The Quaternary deposits at Ringneill Quay and Ardmillan, Co. Down. Proceedings of the Royal Irish Academy 61C: 41-77.

Stillman CJ. 1968. The post-glacial change in sea level in southwest Ireland: new evidence from freshwater deposits on the floor of Bantry Bay. Scientific Proceedings of the Royal Dublin Society 3A: 125-127.

Telford MB. 1978. Glenveagh Forest Park: The past and present vegetation. Unpublished PhD thesis, University of Dublin (TCD). 
Tooley MJ. 1977. The Isle of Man, Lancashire Coast and Lake District, Field Guide A4, X INQUA Congress. Geo. Abstracts Ltd: Norwich.

Tooley MJ. 1978a. Sea-Level Changes in North-West England During the Flandrian Stage. Clarendon Press: Oxford.

Tooley MJ. 1978c. Interpretation of Holocene sea-level changes. Geologiska Foreningens I Stockholm Forhandlingar 100: 203-212.

Tooley MJ. 1985. Sea-level changes and coastal morphology in North-West England. In The Geomorphology of North-West England, Johnson RH (ed). Manchester University Press: Manchester; 94-121.

Trautman MA, Willis EH. 1966. Radiocarbon 8: 161-203.

Wilson HE. 1972. Regional geology of Northern Ireland. HMSO.

Zong Y, Tooley M. 1996. Holocene sea-level changes and crustal movements in Morecambe Bay, Northwest England. Journal Quaternary Science 11: 43-58. 
Author's Final Review Copy - TARA (http://www.tara.tcd.ie)

\section{Table Captions}

Table 1: Source(s) of RSL data from Ireland and UK (west coast) sites 


\section{Figure captions}

Figure 1: Time-space evolution of the Irish component of BIM- 1 (32 - 16ka cal. BP) (Adapted from Shennan et al., - 2006a)

Figure 2: Location map of the $30 \mathrm{RSL}$ time-series records

Figure 3: RSL predictions generated by BIM- 1 (solid line); Model A (long dashed line) and Model B (dotted line)

Figure 4: $\quad$ BIM- 1 RSL isobase map at $6 \mathrm{ka}$ BP

Figure 5: RSL predictions generated by BIM- 1 (solid line); Model C (long dashed line) and Model D (dotted line)

Figure 6: Time-space evolution of our 'best fit' ice model (Model E) (32-16ka cal. BP)

Figure 7: Percentage volumetric change of Model $\mathrm{E}$ in the period 26-15ka BP

Figure 8: RSL predictions generated by BIM- 1 (solid line) and Model E (long dashed line)

Figure 9: RSL predictions generated by running BIM- 1 with $\mathrm{V}_{\cup M} 5 \times 10^{20} \mathrm{~Pa} \mathrm{~s}$ (solid line), 4 $\times 10^{20} \mathrm{~Pa}$ s (long dashed line) and $3 \times 10^{20} \mathrm{~Pa} \mathrm{~s}$ (dotted line)

Figure 10: RSL predictions generated by running BIM- 1 with $\mathrm{V}_{\mathrm{UM}} 5 \times 10^{20} \mathrm{~Pa}$ S (solid line) and Model E with $\mathrm{v}_{\mathrm{UM}} 4 \times 10^{20} \mathrm{~Pa}$ (long dashed line)

Figure 11: Model E RSL isobase map at $6 \mathrm{ka} B P$ run with $\mathrm{v}_{\mathrm{UM}} 4 \times 10^{20} \mathrm{~Pa} \mathrm{~s}$ 


\section{References}

Ballantyne CK. 1997. Periglacial trimlines in the Scottish Highlands. Quaternary International 38/39: 119-136.

Ballantyne CK. McCaroll, D., Nesje, A., Dahl, S.O., Stone, J.O., Fifield, L.K., 1998a. High resolution reconstruction of the last ice sheet in NW Scotland. Terra Nova 10(1): 63-67.

Ballantyne CK, McCaroll D, Nesje A, Dahl SO, Stone JO. 1998b. The last ice sheet in North-West Scotland: reconstruction and implications. Quaternary Science Reviews 17: 11491184.

Ballantyne CK, McCarroll D, Stone JO. 2006. Vertical dimensions and age of the Wicklow Mountains ice dome, Eastern Ireland, and implications for the extent of the last Irish ice sheet. Quaternary Science Reviews 25: 2048-2058

Bassett SE, Milne GA, Mitrovica JX, Clark PU. 2005. Ice Sheet and Solid Earth Influences on Far-Field Sea-Level Histories. Science 309: 925-928.

Boulton GS, Jones AS, Clayton KM, Kenning MJ. 1977. A British ice-sheet model and patterns of glacial erosion and deposition in Britain. In British Quaternary Studies: Recent Advances, Shotton FW (ed). Clarendon Press: Oxford; 231-246.

Bowen DQ. 1973. The Pleistocene history of the Irish Sea. Proceedings of the Geologists' Association 84: 249-272.

Bowen DQ, Phillips FM, McCabe AM, Knutz PC, Sykes GA. 2002. New data for the Last 
Glacial Maximum in Great Britain and Ireland. Quaternary Science Reviews 21: 89-101.

Brooks AJ, Edwards RJ. 2006. The development of a sea-level database for Ireland. Irish Journal of Earth Science 24:13-27.

Carr SJ, Holmes R, van der Meer JJM, Rose J. 2006. The Last Glacial Maximum in the North Sea Basin: micromorphological evidence of extensive glaciation. Journal of Quaternary Science 21(2): 131-153.

Clark CD, Meehan RT. 2001. Subglacial bedform geomorphology of the Irish Ice Sheet reveals major configuration changes during growth and decay. Journal of Quaternary Science 16(5): 483-496.

Colhoun EA, Dickson JH, McCabe AM, Shotton FW. 1972. A Middle Midlandian freshwater series at Derryvree, Maguiresbridge, County Fermannagh, Northern Ireland. Proceedings of the Royal Society 180B: 273-292.

Coudé A. 1977. Formations superficielles et dernière grande glaciation en Irlande Occidentale. Centre National de la Récherche Scientifique, Centre de Géomorphologie de Caen, Bulletin 22: 1-51

Coxon P. 1997. Pleistocene Climate Change: the Evidence from Irish Sequences. In Global Change and the Irish Environment, Sweeney J (ed). Royal Irish Academy: Dublin; 1735.

Dziewonski AM, Anderson DL. 1981. Preliminary reference Earth model. Physics of the Earth and Planetary Interiors 25: 297-356. 
Edwards RJ. 2005. Sea Levels: Abrupt events and mechanisms of change. Progress in Physical Geography 29(4): 599-608.

Evans D, Kenolty N, Dobson MR, Whittington RJ. 1980. The geology of the Malin Sea. Institute of Geological Sciences Report 79/15: 1-44.

Evans DJA, O'Cofaigh C. 2003. Depositional evidence for marginal oscillations of the Irish Sea ice stream in southeast Ireland during the last glaciation. Boreas 32: 76-101.

Farrell WE, Clark JA. 1976. On postglacial sea level. Geophysical Journal of the Royal Astronomical Society 46: 647-667.

Gehrels R. 2004. Saltmarsh fieldwork, stratigraphy, micropalaeontology, transfer functions: Ireland. In Late Holocene Shallow Marine Environments Of Europe (HOLSMEER) final Report, Scourse J (ed). 107-120.

Harmon M. 2006. Saltmarsh Archives of Relative Sea-Level Change During the Late Holocene in the North of Ireland. Unpublished PhD thesis, Queens University: Belfast.

Hegarty S. 2004. Limits of Midlandian glaciation in south-eastern Ireland. Irish Geography 37(1): $60-76$.

Heyworth A, Kidson C. 1982. Sea-level changes in southwest England and Wales. Proceedings of the Geological Association 93: 91-111. 
Hiemstra JF, Evans DJA, Scourse JD, McCarroll D, Furze MFA, Rhodes E. 2006. New evidence for a grounded Irish Sea glaciation of the Isles of Scilly, UK. Quaternary Science Reviews 25: 299-309.

Horton BP, Edwards RJ, Lloyd JM. 2000. Implications of a microfossil transfer function in Holocene sea-level studies. In: Shennan, I., Andrews, J.E. (Eds.), Holocene land-ocean interaction and environmental change around the western North Sea. Geological Society of London, Special Publications 166: 41-54.

Johnston P. 1993. The effect of spatially non-uniform water loads on the prediction of sealevel change. Geophysical Journal International 114: 615-634.

Kelley JT, Cooper JAG, Jackson DWT, Belknap DF, Quinn RJ. 2006. Sea-level change and inner shelf stratigraphy off Northern Ireland. Marine Geology 232(1-2): 1-15.

Kendall RA, Mitrovica JX, Milne GA. 2005. On post-glacial sea level - II. Numerical formulation and comparative results on spherically symmetric models. Geophysics Journal International 161: 679-706.

Kidson C, Heyworth A. 1979. Sea-level. In Proceedings of the 1978 International Symposium on Coastal evolution in the Holocene. Universidade de São Paulo; 1-28.

Lambeck K. 1991. Glacial rebound and sea-level change in the British Isles. Terra Nova 3 : 379-389.

Lambeck K. 1993a. Glacial rebound of the British Isles-I. Preliminary model results. Geophysical Journal International 115: 941-959. 
Lambeck K. 1993b. Glacial Rebound of the British Isles-II. A High-Resolution, HighPrecision Model. Geophysical Journal International 115: 960-990.

Lambeck K. 1995. Late Devensian and Holocene shorelines of the British Isles and North Sea from models of glacio-hydro-isostatic rebound. Journal of the Geological Society of London 152: 437-448.

Lambeck K. 1996. Glaciation and sea level change for Ireland and the Irish Sea since Late Devensian/Midlandian time. Journal of the Geological Society of London 153: 853-872.

Lambeck K. 2002. Sea Level Change from Mid-Holocene to Recent Time: An Australian Example with Global Implications in Glacial Isostatic Adjustment and the Earth System. In Sea Level, Crustal Deformation, Gravity and Rotation, Mitrovica JX, Vermeersen LLA (eds). AGU Monograph, Geodynamics Series, vol. 29. American Geophysical Union: Washington DC; 33-50.

Lambeck K, Johnston P, Smither C, Nakada M. 1996. Glacial rebound of the British Isles III. Constraints on mantle viscosity. Geophysical Journal International 125: 340-354.

Lambeck K, Purcell AP. 2001. Sea-level change in the Irish Sea since the Last Glacial Maximum: constraints from isostatic modelling. Journal of Quaternary Science 16(5): 497505.

Lewis CA. 1976. The Knockmealdown Mountains: a glacial nunatak. Irish Geography 9: 18-28. 
McCabe AM. 1985. Glacial geomorphology. In The Quaternary History of Ireland, Edwards KJ, Warren WP (eds). Academic Press: London; 67-93.

McCabe AM. 1995. Quaternary geology. In: Northwest Donegal, Irish Association for Quaternary Studies (IQUA) Field Guide No. 19, Wilson P (ed). IQUA: Dublin; 15-20.

McCabe AM. 1997. Geological constraints on geophysical models of RSL change during deglaciation of the West Irish Sea Basin. Journal of the Geological Society of London 154: 601-604.

McCabe AM. 2005. Sedimentology of the Barna Drumlin, Galway Bay. In The Quaternary of Central Western Ireland, Coxon P (ed). Quaternary Research Association Field Guide: London; 64-70.

McCabe AM, Haynes JR, Macmillan NF. 1986. Late-Pleistocene tidewater glaciers and glaciomarine sequences from north County Mayo, Republic of Ireland. Journal of Quaternary Science 1: 73-84.

McCabe AM, Haynes JR. 1996. A late Pleistocene intertidal boulder pavement from an isostatically emergent coast, Dundalk Bay, eastern Ireland. Earth Surface Processes and Landforms 21: 555-572.

McCabe M, Knight J, McCarron S. 1998. Evidence for Heinrich 1 in the British Isles. Journal of Quaternary Science 13(6): 549-568.

McCabe AM, Clark PU. 1998. Ice sheet variability around the circum-North Atlantic Ocean during the last deglaciation. Nature 392: 373-377. 
McCabe AM, Clark PU. 2003. Deglacial chronology from County Donegal, Ireland: implications for deglaciation of the British-Irish ice sheet. Journal of the Geological Society of London 160: 847-855.

McCabe AM, Clark PU, Clark J. 2005. AMS 14C dating of deglacial events in the Irish Sea Basin and other sectors of the British-Irish ice sheet. Quaternary Science Reviews 24: 16731690.

McCarroll D, Ballantyne CK. 2000. The last ice sheet in Snowdonia. Journal of Quaternary Science 15: 765-778.

Milne GA, Mitrovica JX. 1996. Postglacial sea-level change on a rotating Earth: first results from a gravitionally self-consistent sea-level equation. Geophysical Journal International 126: F13-F20.

Milne GA, Mitrovica JX, Davis JL. 1999. Near-field hydroisostasy: the implementation of a revised sea-level equation. Geophysical Journal International 139: 464-482.

Milne GA, Shennan I, Youngs BAR, Waugh AI, Teferle FN, Bingley RM, Bassett SE, Cuthbert-Brown C, Bradley SL. (2006). Modelling the glacial isostatic adjustment of the UK region. Philosophical Transactions of the Royal Society.

Mitchell GF. 1977. Raised Beaches and Sea Levels. In British Quaternary Studies-recent advances, Shotton FW (ed). Clarendon Press: Oxford; 169-186.

Mitrovica JX, Peltier WR. 1991. On postglacial geoid subsidence over the equatorial oceans. Journal of Geophysical Research 96: 20053-20071. 
Mitrovica JX, Peltier WR. 1995. Constraints on mantle viscosity based upon the inversion of past-glacial uplift data from the Hudson Bay region. Geophysical Journal International 122 : 353-377.

Mitrovica JX, Milne GA. 2003. On post-glacial sea level: I. General theory. Geophysical Journal International 154: 253-267.

Murray Gray J, Coxon P. 1991. The Loch lomond Stadial glaciation in Britain and Ireland. In Glacial Deposits in Great Britain and Ireland, Ehlers J, Gibbard PL, Rose J (eds). AA Bakema: Rotterdam; 89-105.

Nakada M, Lambeck K. 1987. Glacial rebound and relative sea-level variations: a new appraisal. Geophysical Journal of the Royal Astronomical Society 90: 171-224.

Nakada M, Lambeck K. 1989. Late Pleistocene and Holocene sea-level change in the Australian region and mantle rheology. Geophysical Journal International 96: 497-517.

O'Cofaigh C, Evans DJA. 2001. Sedimentary evidence for deforming bed conditions associated with a grounded Irish Sea Glacier, southern Ireland. Journal of Quaternary Science 16(5): 435-454.

Peltier WR. 1974. The impulse response of a Maxwell Earth. Reviews of Geophysics 12: 649-669.

Peltier WR. 1996. Mantle viscosity and ice-age ice sheet topography. Science 273: 1359. 
Peltier WR. 1998. Postglacial variations in the level of the sea: implications for climate dynamics and solid-earth geophysics. Reviews of Geophysics 36: 603-689.

Peltier WR. 2004. Global glacial isostasy and the surface of the ice-age earth: The ICE-5G (VM2) model and GRACE. Annual Review of Earth and Planetary Sciences 32: 111.

Peltier WR, Andrews JT. 1976. Glacial isostatic adjustment I. The forward problem, Geophysical Journal of the Royal Astronomical Society 46: 605-646.

Peltier WR, Shennan I, Drummond R, Horton BP. 2002. On the postglacial isostatic adjustment of the British Isles and the shallow viscoelastic structure of the Earth. Geophysical Journal International 148: 443-475.

Preuss H. 1979. Progress in computer evaluation of sea level data within the IGCP Project no. 61. Proceedings of the 1978 International Symposium of coastal evolution in the Quaternary: 104-134.

Rae A, Harrison S, Mighall T, Dawson AG. 2004. Periglacial trimlines and former nunataks of the Last Glacial Maximum (LGM) in the vicinity of the gap of Dunloe, southwest Ireland. Journal of Quaternary Science 19(1): 87-97.

Scourse JD, Austin WEN, Bateman RM, Catt JA, Evans CDR, Robinson JE, Young JR. 1990. Sedimentology and micropalaeontology of glaciomarine sediments from the central and southwestern Celtic Sea. Special Publication of the Geological Society of London 53: 329347. 
Scourse JD. 1991. Late Pleistocene stratigraphy and palaeobotany of the Isles of Scilly. Philosophical Transactions of the Royal Society of London B334: 405-448.

Sejrup HP, Haflidason H, Aarseth I, King E, Forsberg KF, Long D, Rokoengen K. 1994. Late Weichselian glaciation history of the northern North Sea. Boreas 23: 1-13.

Sejrup HP, Hjelstuen BO, Dahlgren KIT, Haflidason H, Kuijpers A, Nygard A, Praeg D, Stoker MS, Vorren T. 2005. Pleistocene glacial history of the NW European continental margin. Marine and Petroleum Geology 22: 1111-1129.

Shaw J. 1985. Holocene coastal evolution, Co. Donegal, Ireland. Unpublished PhD Thesis, The University of Ulster: Coleraine.

Shaw J, Carter RWG. 1994. Coastal peats from northwest Ireland: implications for Late Holocene RSL change and shoreline evolution. Boreas 23: 74-91.

Shennan I. 1982. Interpretation of Flandrian sea-level data from the Fenland, England. Proceedings of the Geologists' Association 83(1): 53-63.

Shennan I. 1986. Flandrian sea-level changes in the Fenland I. The geographical setting and evidence of relative sea-level changes. Journal of Quaternary Science 1(2): 119-154.

Shennan I. 1989. Late Quaternary sea-level changes: measurement, correlation and future applications - the international significance of IGCP Project 200. Journal of Quaternary Science 4: 3-5. 
Shennan I, Lambeck K, Flather R, Horton BP, McArthur JJ, Innes JB, Lloyd JM, Rutherford MM, Wingfield R. 2000c. Modelling western North Sea Palaeogeographies and tidal changes during the Holocene. Geological Society of London Special Publications 166: 299-319.

Shennan I, Horton BP, Innes JB, Gehrels WR, Lloyd JM, McArthur JJ, Rutherford MM. 2000d. Late Quaternary sea-level changes, crustal movements and coastal evolution in Northumberland, UK. Journal of Quaternary Science 15: 215-237.

Shennan I, Peltier WR, Drummond R, Horton BP. 2002. Global to local scale parameters determining relative sea-level changes and the post-glacial isostatic adjustment of Great Britain. Quaternary Science Reviews 21: 397-408.

Shennan I, Horton BP. 2002. Holocene land- and sea-level changes in Great Britain Journal of Quaternary Science 17: 511-526.

Shennan I, Bradley S, Milne G, Brooks AJ, Bassett S, Hamilton S, Hillier C, Hunter A, Woodal R. 2006a. Relative sea-level changes, glacial isostatic modelling and ice sheet reconstructions from the British Isles since the last glacial maximum. Journal of Quaternary Science 21: 585-599.

Shennan I, Hamilton S, Hillier C, Hunter A, Woodall R, Bradley S, Milne G, Brooks A, Bassett S. 2006b. Relative sea-level observations in western Scotland since the last glacial maximum for testing models of glacial isostatic land movements and ice-sheet reconstructions. Journal of Quaternary Science 21(6): 601-613. 
Smith DE. 2005. Evidence for secular sea surface level changes in the Holocene raised shorelines of Scotland, UK. Journal of Coastal Research 42: 26-42.

Stephens N, Synge F. 1965. Late Pleistocene shorelines and drift limits in North Donegal. Proceedings of the Royal Irish Academy 64B: 131-153.

Stephens N, McCabe AM. 1977. Late-Pleistocene ice movements and patterns of Late and Post glacial shorelines on the east coast of Ulster. In The Quaternary history of the Irish Sea, Kidson C, Tooley MJ (eds). Sea House Press: Liverpool; 179-198.

Stuiver M, Reimer PJ, Reimer R. 2005. Radio carbon calibration program revision 5.0.1. Copyright 1986-2005.

Svendsen JI, Alexanderson H, Astakhov VI, Demidov I, Dowdeswell JA, Funder S, Gataullin V, Henriksen M, Hjort C, Houmark-Nielsen M. 2004. Late Quaternary ice sheet history of northern Eurasia. Quaternary Science Reviews 23: 1229-1271.

Synge FM. 1977a. The coasts of Leinster. In The Quaternary history of the Irish Sea, Kidson C, Tooley MJ (eds). Seel House Press: Liverpool; 179-198.

Synge FM. 1977b. Records of sea levels during the Late Devensian. Philosophical Transactions of the Royal Society of London 280B: 211-228.

Synge F, Stephens N. 1966. Late and post glacial shorelines and ice limits in Argyll and north-east Ulster. Transactions of the Institution of British Geographers 39: 101-125. 
Thomas GSP, Chiverrell RC, Huddart D. 2004. Ice-marginal depositional responses to readvance episodes in the Late Devensian deglaciation of the Isle of Man. Quaternary Science Reviews 23: 85-106.

Thomas GSP, Chiverrell RC. 2006. A model of subaqueous sedimentation at the margin of the Late Midlandian Irish Ice Sheet, Connemara, Ireland, and its implications for regionally high isostatic sea-levels. Quaternary Science Reviews 25: 2868-2893

Thorp PW. 1986. A mountain ice field of Loch Lomond Stadial age, western Grampians. Boreas 15: 83-97.

Tooley MJ. 1978. Sea-level changes in North-west England during the Flandrian Stage. Clarendon Press: Oxford.

Van de Plassche O. 1986. Sea-level Research: A Manual for the Collection and Evaluation of Data. Geo Books: Norwich.

Walcott RI. 1972. Late Quaternary vertical movements in Eastern North America. Reviews of Geophysics and Space Physics 10: 849-884.

Warren WP. 1992. Drumlin orientation and the pattern of glaciation in Ireland. Sveriges Geologiska Undersokning, Research Papers, Series Ca 81: 359-366. 
Table 1

\begin{tabular}{|c|c|c|c|c|c|}
\hline Site & Name & Lat. & Long. & No. data & Reference(s) \\
\hline 01 & Dublin & 53.138 & -6.123 & $0(+7)$ & Mitchell (1976) \\
\hline 02 & North Wexford & 52.521 & -6.232 & 1 & Sinnott, (1999) \\
\hline 03 & South Wexford & 52.315 & -6.412 & $11(+5)$ & $\begin{array}{l}\text { Mitchell (1977); Dresser, (1980); } \\
\text { Carter \& Orford, (1982); Orford \& Carter (1982b); } \\
\text { Maloney, (1985); Sinnott, (1999) }\end{array}$ \\
\hline 04 & East Cork & 51.949 & -7.935 & $10(+1)$ & $\begin{array}{l}\text { Mitchell, (1976); Mitchell, (1977); } \\
\text { Carter et al., (1989); Sinnott, (1999) }\end{array}$ \\
\hline 05 & West Cork & 51.607 & -8.906 & $13(+5)$ & $\begin{array}{l}\text { Stillman, (1968); Buzer, (1980); Sinnott, (1999); } \\
\text { Devoy et al., (2004) }\end{array}$ \\
\hline 06 & Kerry & 52.107 & -9.916 & $1(+10)$ & Carter et al., (1989) \\
\hline 07 & South Clare & 52.601 & -9.721 & $0(+5)$ & $\begin{array}{l}\text { Pearson, (1979); Devoy et al., (1996); } \\
\text { O'Sullivan, (2001) }\end{array}$ \\
\hline 08 & Mid Shannon & 52.601 & -9.213 & $0(+3)$ & O'Sullivan, (2001) \\
\hline 09 & Inner Shannon & 52.658 & -8.705 & $0(+9)$ & O’Sullivan, (2001) \\
\hline 10 & Galway & 53.238 & -9.305 & $0(+1)$ & Mitchell (1976) \\
\hline 11 & Connemara & 53.679 & -9.900 & $0(+10)$ & Jessen (1949); Devoy et al., (1996) \\
\hline 12 & North Mayo & 54.320 & -9.540 & $0(+8)$ & McCabe et al., $(1986,2005)$ \\
\hline 13 & Sligo & 54.258 & -8.607 & $0(+1)$ & Burenhuit, (1980) \\
\hline 14 & West Donegal & 54.885 & -8.431 & $8(+11)$ & $\begin{array}{l}\text { Smith \& Pilcher., (1973); Telford, (1978); } \\
\text { Pearson, (1979); Carter, (1982); } \\
\text { Gaulin et al., (1983); Shaw, (1985); } \\
\text { Shaw and Carter, (1994); HOLSMEER, (2004); } \\
\text { Harmon, (2006) }\end{array}$ \\
\hline 15 & North Donegal & 55.160 & -7.979 & $3(+6)$ & Shaw, (1985); Shaw and Carter, (1994) \\
\hline 16 & Lough Swilly & 55.119 & -7.399 & $0(+8)$ & $\begin{array}{l}\text { Colhoun et al., (1973); Shaw and Carter, (1994); } \\
\text { McCabe \& Clark (2003) }\end{array}$ \\
\hline 17 & Derry & 55.15 & -6.851 & $0(+10)$ & $\begin{array}{l}\text { Pearson, (1979); Battarbee et al., (1982); } \\
\text { Carter \& Wilson, (1990); Woodman, (unpub.*); } \\
\text { Bazley et al., (unpub.*) }\end{array}$ \\
\hline 18 & North Antrim & 55.052 & -6.014 & $0(+8)$ & $\begin{array}{l}\text { Mitchell \& Stephens, (1974); Prior et al., (1981); } \\
\text { Smith et al., (1974) }\end{array}$ \\
\hline 19 & North Down & 54.55 & -5.658 & $0(+15)$ & $\begin{array}{l}\text { Stephens \& Collins, (1960); } \\
\text { Morrison \& Stephens, (1961); } \\
\text { Morrison \& Stephens, (1965); } \\
\text { Manning et al., (1970); Smith et al., (1974); } \\
\text { Pearson \& Pilcher, (1975); } \\
\text { Harkness \& Wilson, (1979); McCabe \& Clark, (1998) }\end{array}$ \\
\hline 20 & South Down & 54.29 & -5.774 & $2(+10)$ & $\begin{array}{l}\text { Hubbs, Bien \& Suess, (1965); Dresser et al., (1973); } \\
\text { Singh \& Smith, (1973); Carter, (1982); } \\
\text { McCabe \& Clark, (1998) }\end{array}$ \\
\hline 21 & Dundalk & 53.947 & -6.340 & $0(+16)$ & $\begin{array}{l}\text { Jessen, (1949); Mitchell, (1971); Penney, (1983); } \\
\text { McCabe \& Haynes, (1996); } \\
\text { McCabe \& Clark, (1998); McCabe et al., (2005) } \\
\text { Clark et al., (submitted }{ }^{+} \text {) }\end{array}$ \\
\hline 22 & Islay & 55.808 & -6.343 & 8 & Shennan et al., (submitted) \\
\hline 23 & Knapdale & 55.784 & -5.561 & $9(+7)$ & Shennan et al., (submitted) \\
\hline 24 & Isle of Man & 54.395 & -4.388 & $12(+2)$ & Tooley (1977); Roberts et al., (submitted) \\
\hline 25 & Morecombe Bay & 54.085 & -2.958 & $21(+3)$ & Tooley (1978a); Birks (1982); Zong \& Tooley (1996) \\
\hline 26 & Lancashire & 53.685 & -2.990 & 42 & Tooley (1978a,c, 1985); Huddart (1992) \\
\hline 27 & North Wales & 53.300 & -3.748 & 9 & $\begin{array}{l}\text { Tooley (1978a); Kidson \& Heyworth (1982); } \\
\text { Bedlington (1993) }\end{array}$ \\
\hline 28 & Mid Males & 52.473 & -4.058 & $14(+3)$ & Heyworth \& Kidson (1982) \\
\hline 29 & SW Wales & 51.658 & -5.066 & 1 & Heyworth \& Kidson (1982) \\
\hline 30 & Cornwall & 50.129 & -5.482 & 7 & Healy (1995) \\
\hline
\end{tabular}

${ }^{*}$ cited in Carter, (1982a); ${ }^{+}$cited in McCabe et al., (2005)

(In the 'No. data' column, bracketed numbers refer to the number of non-primary index points) 
Figure 1

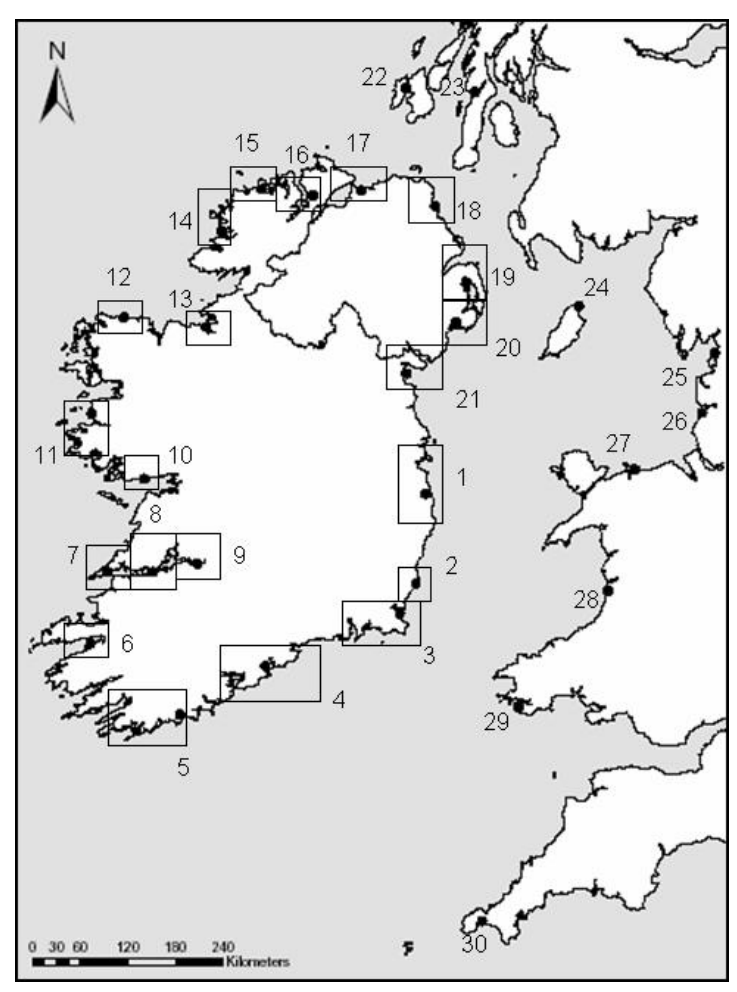


Figure 2
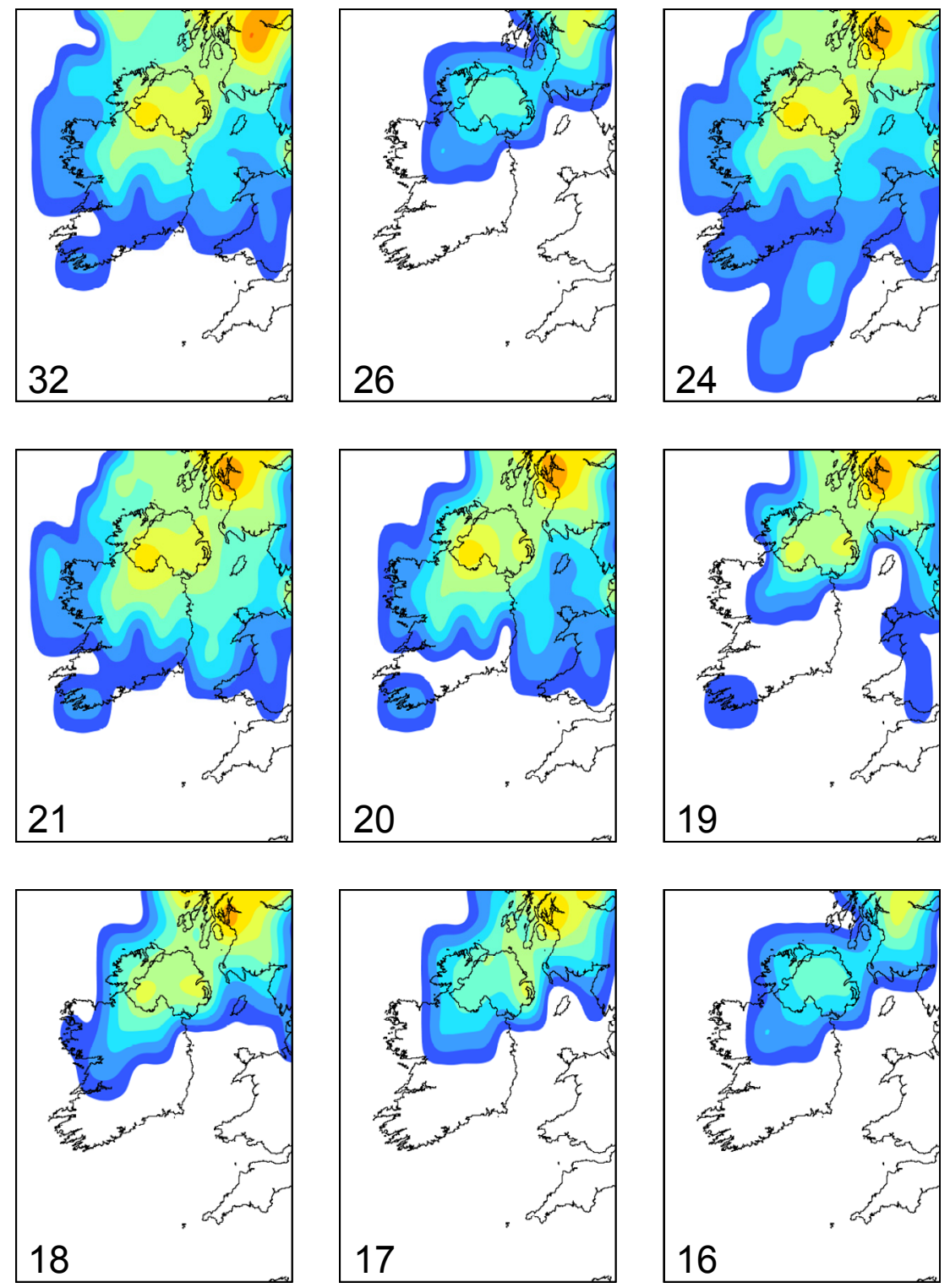

$\begin{array}{lllllllll}125 & 250 & 375 & 500 & 625 & 750 & 875 & 1000 & 1125\end{array}$

Ice thickness, terrain corrected (m) 
Figure 3
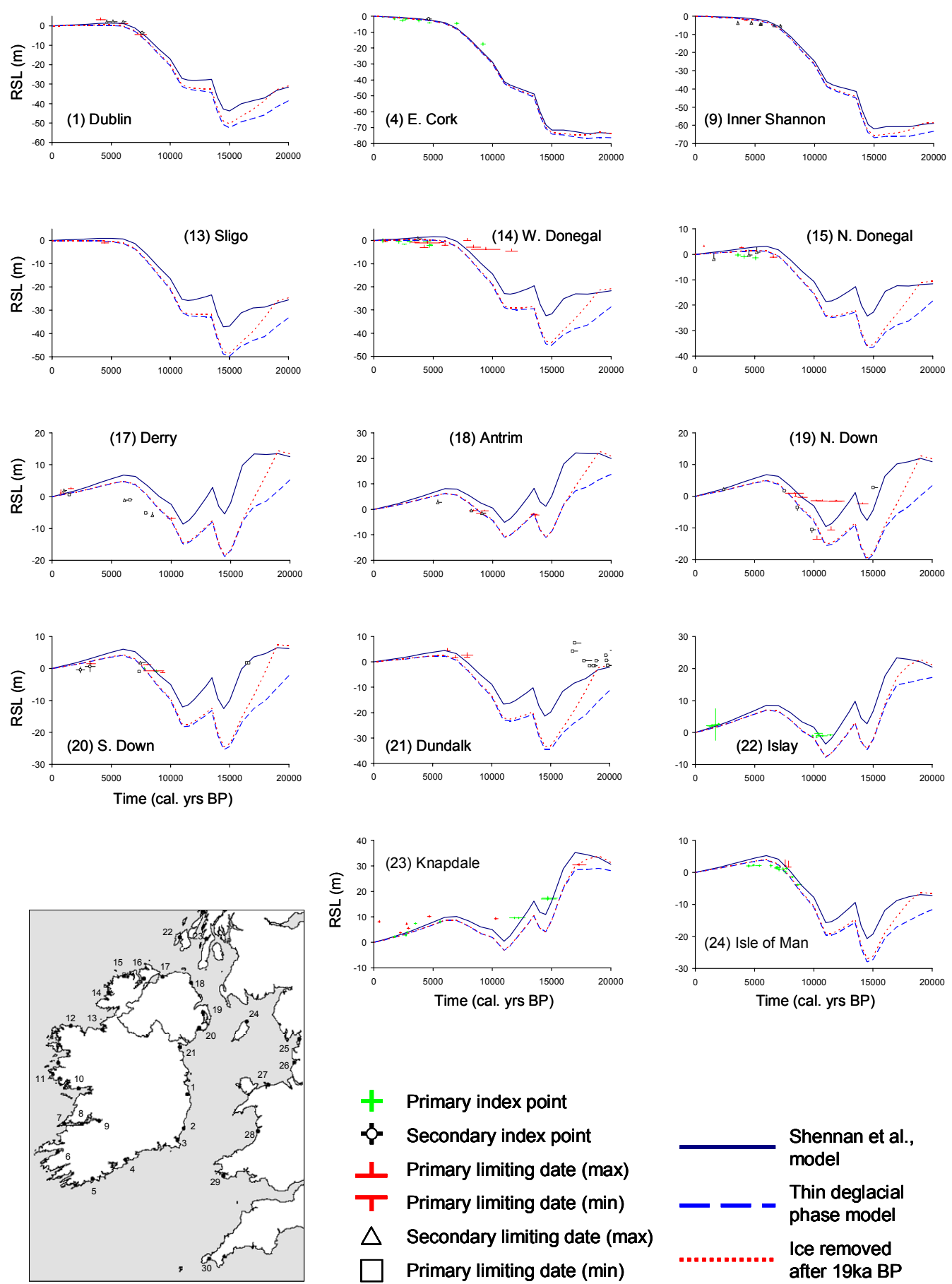
Figure 4

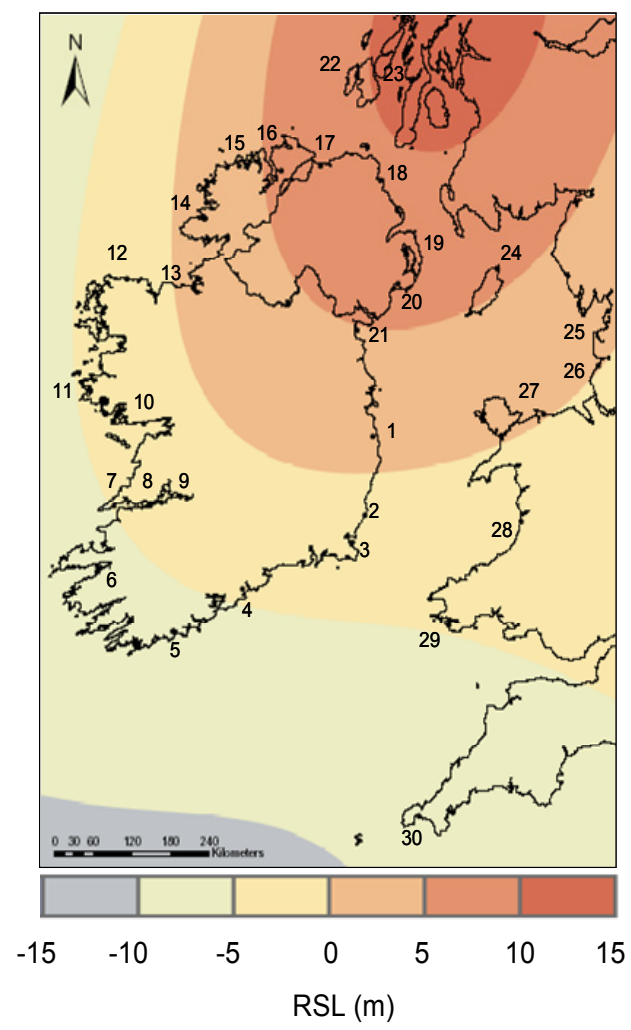


Figure 5
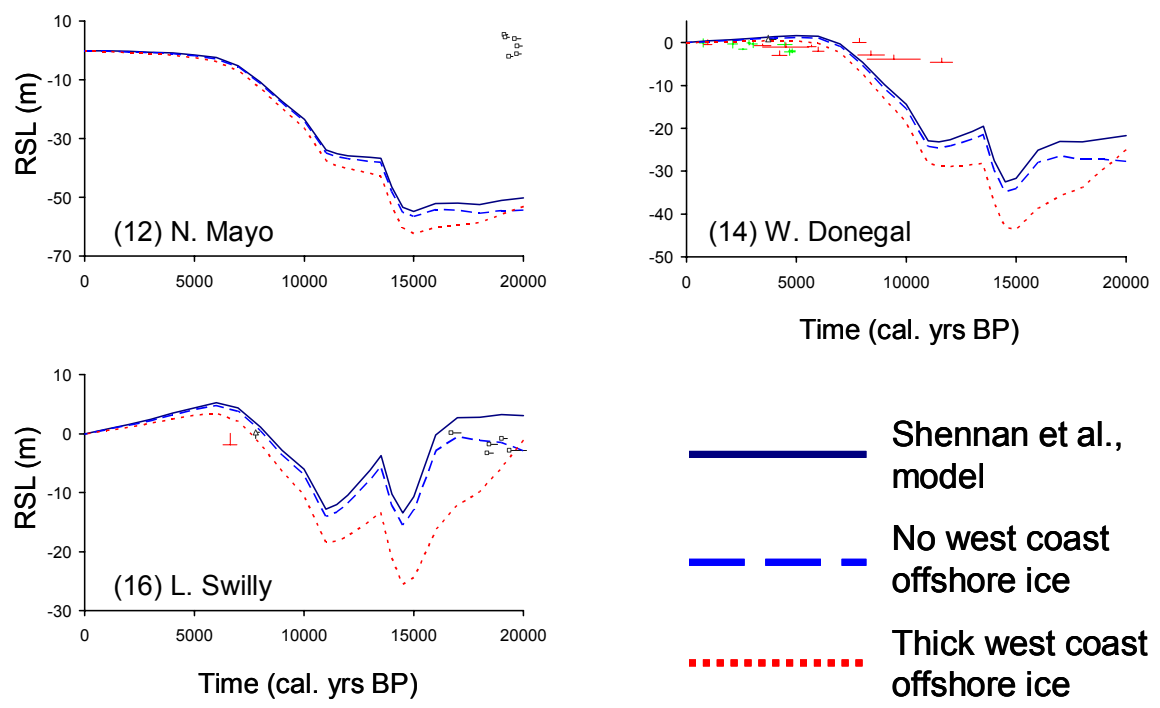
Figure 6
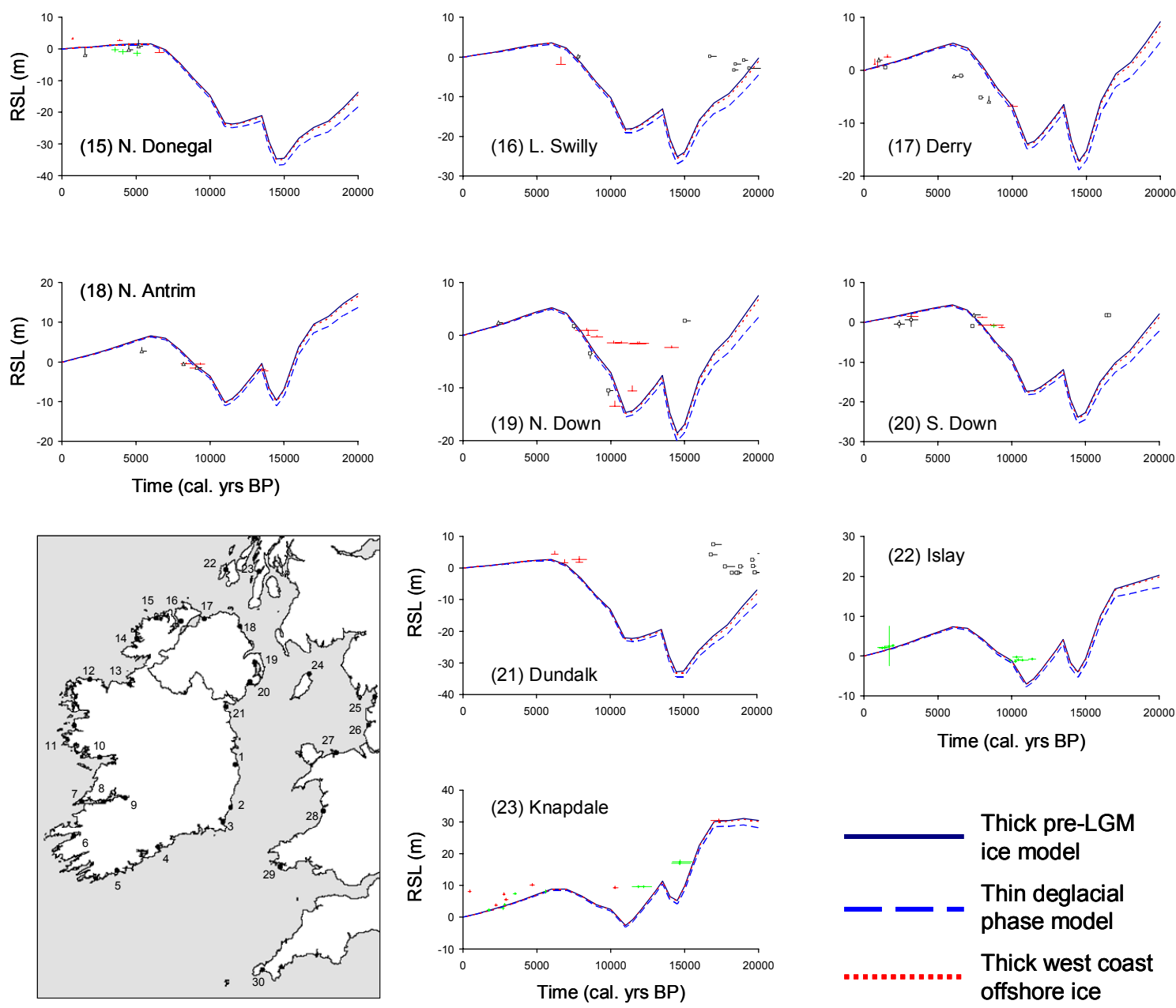
Figure 7
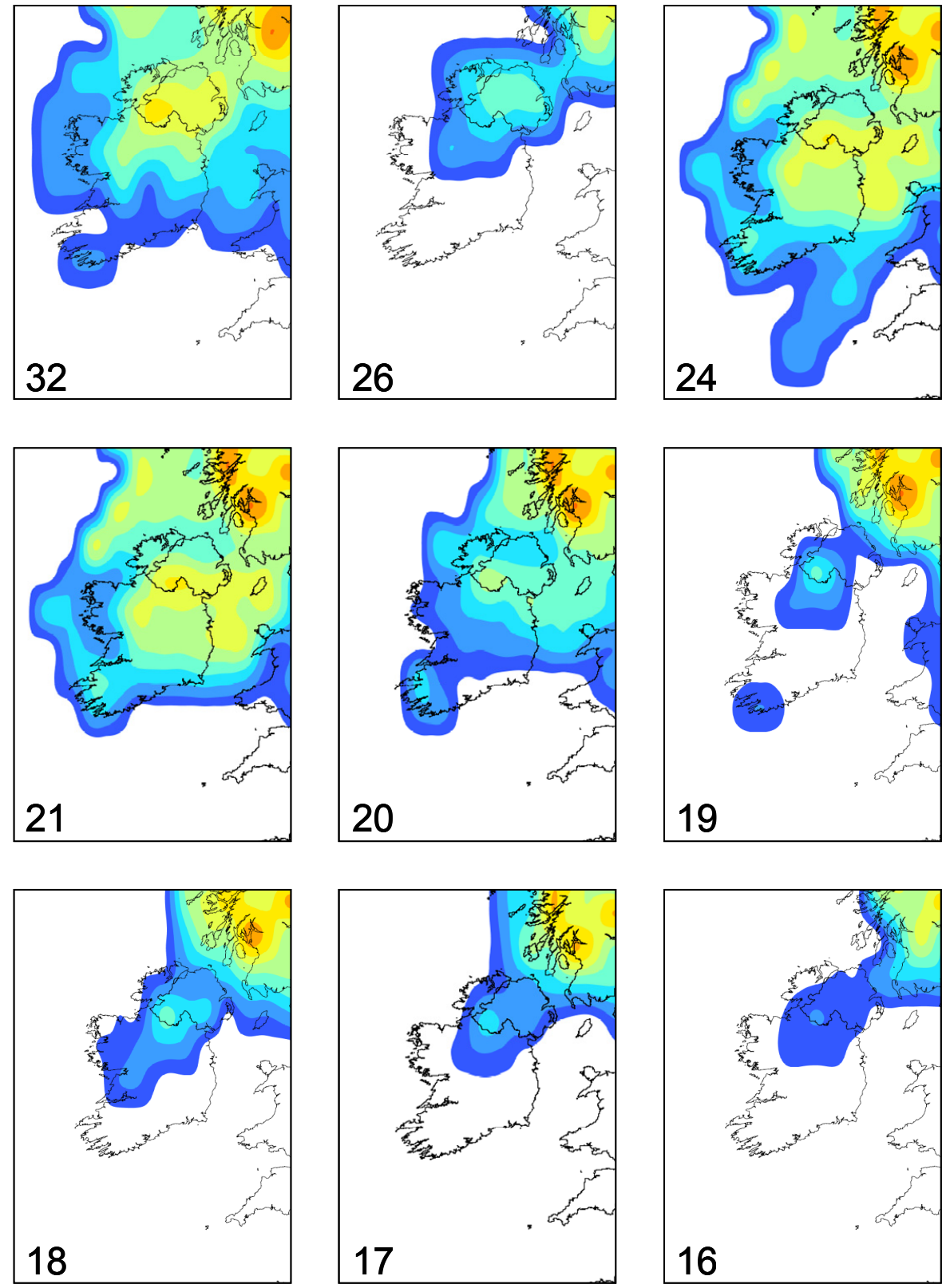

$\begin{array}{lllllllll}125 & 250 & 375 & 500 & 625 & 750 & 875 & 1000 & 1125\end{array}$

Ice thickness, terrain corrected (m) 
Figure 8

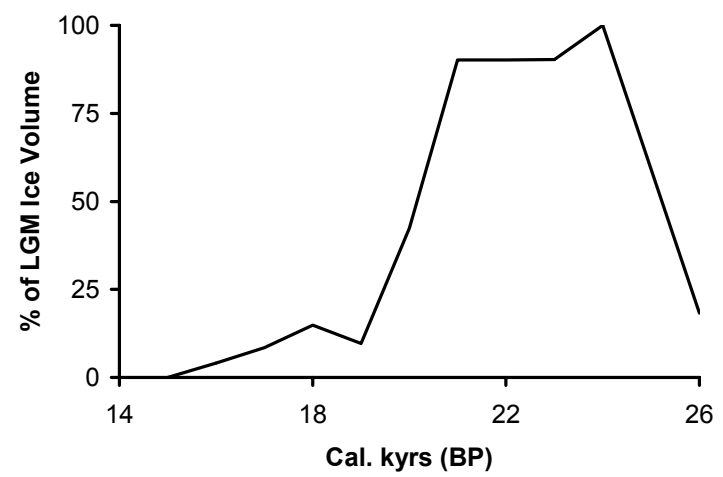


Figure 9
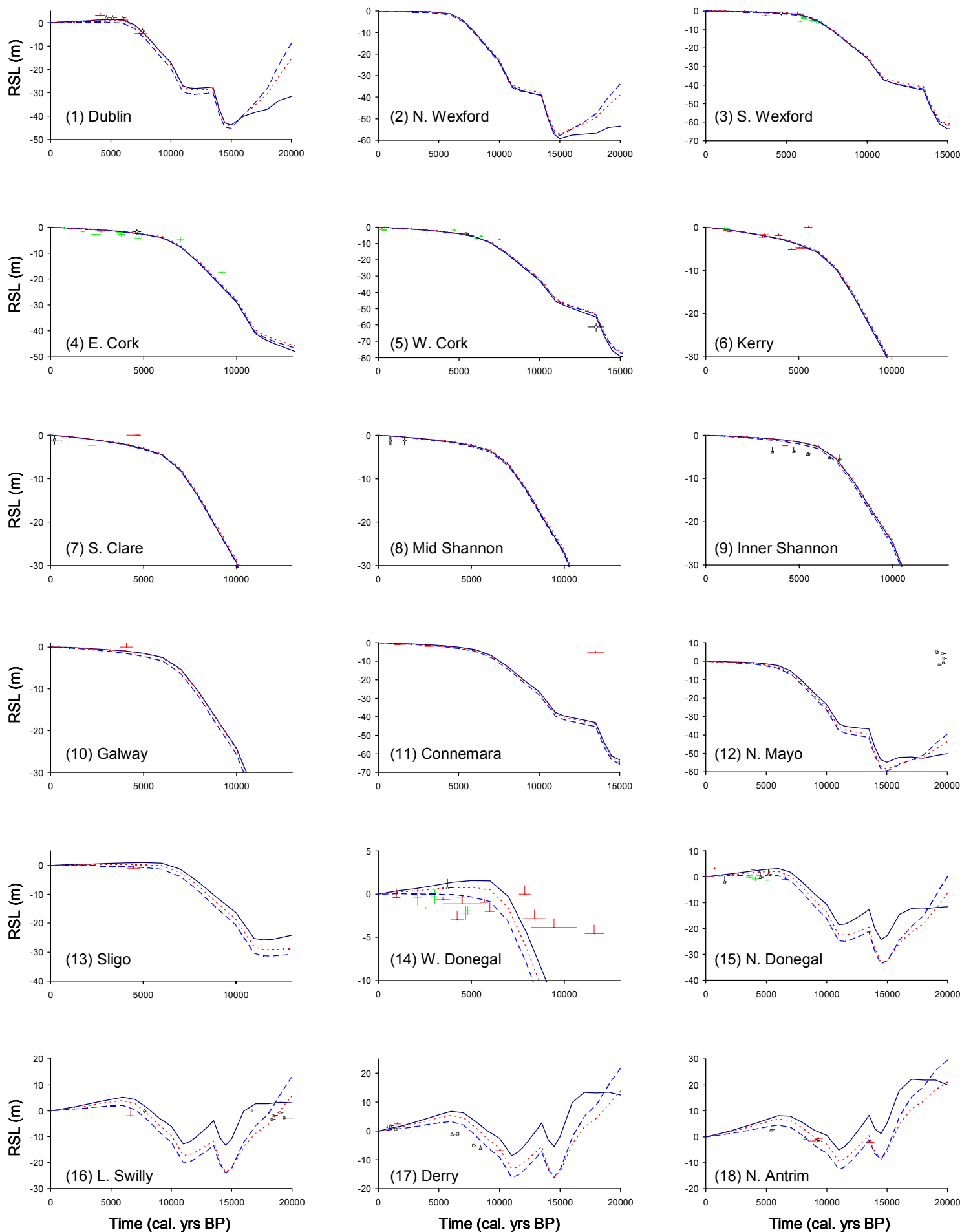
Figure 9... (cont)
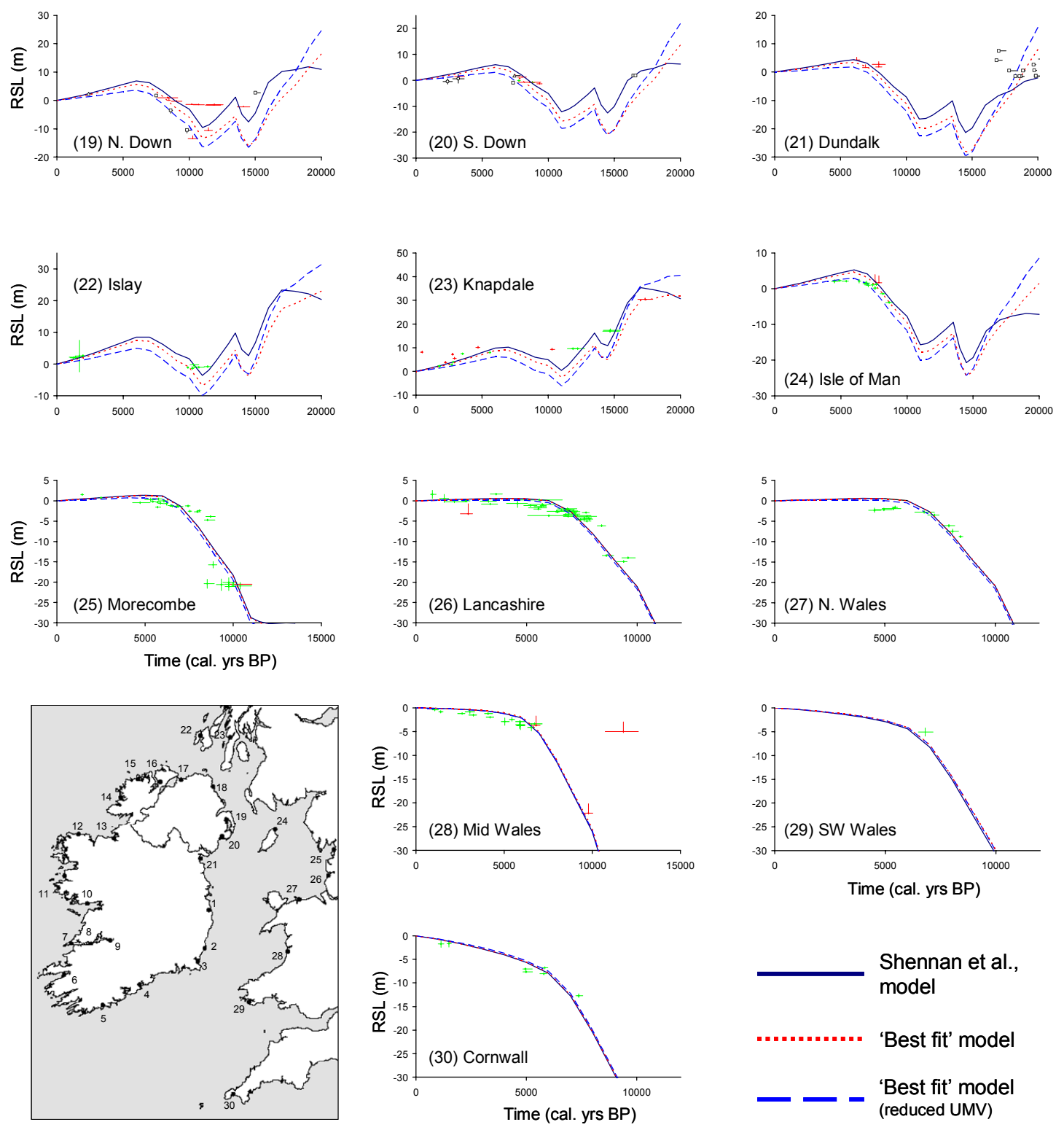
Figure 10

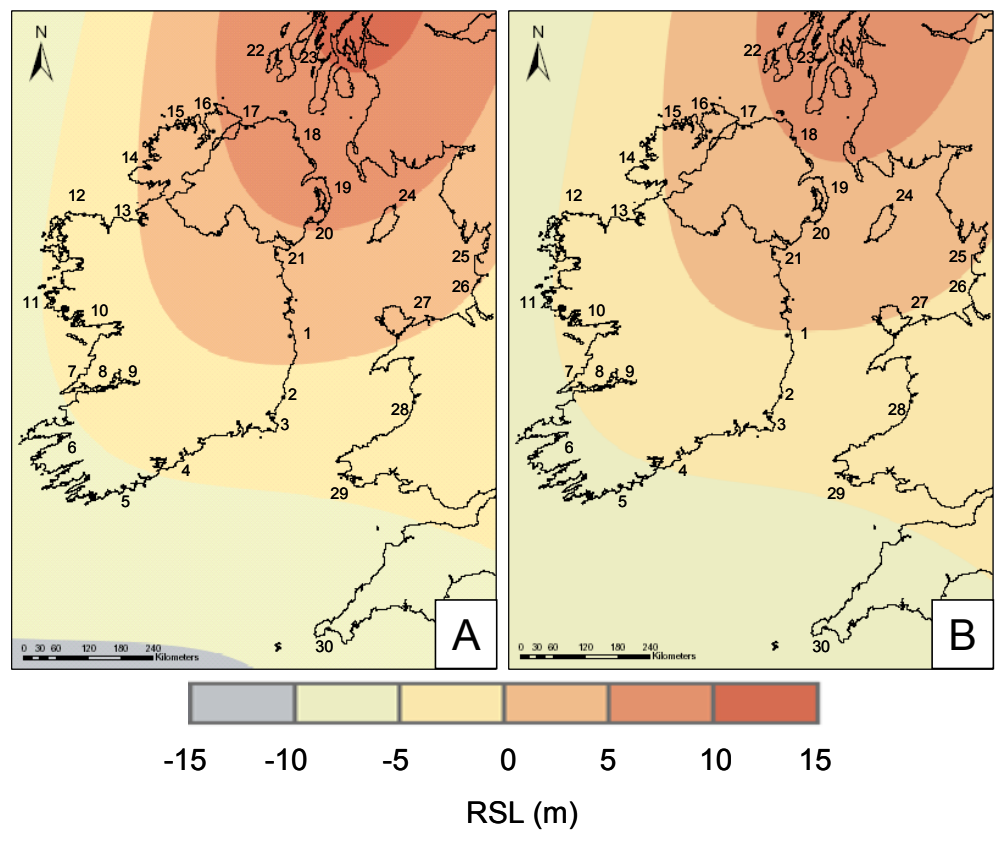


Figure 11
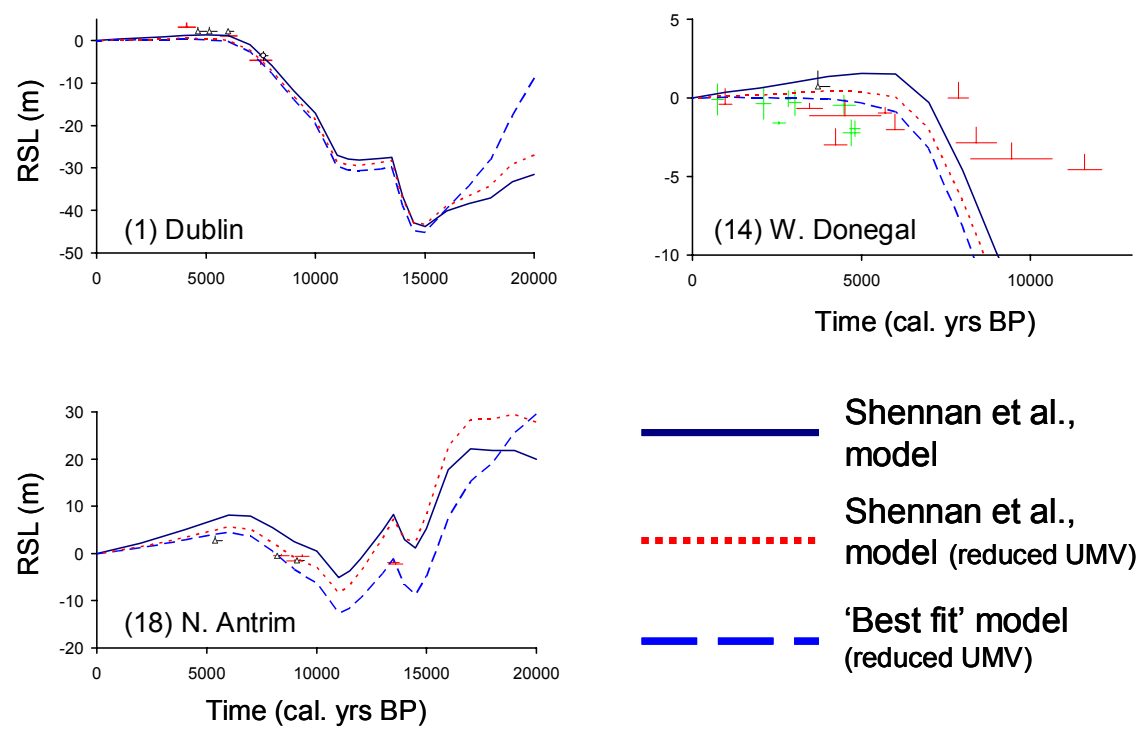


\section{Appendix A: RSL database contributors}

Battarbee RW, Scaife RG, Phetheon SJ. 1982. Palaeoecological evidence for sea-level change in the Bann Estuary in early Mesolithic. In Excavations at Mountsandel, Woodman (ed.): HMSO.

Bedlington DJ. 1993. Holocene sea-level changes and crustal movements in North Wales and Wirral. Unpublished PhD thesis, University of Durham, Durham.

Birks HJB. 1982. Mid-flandrian forest history of Roudsea Wood National Nature Reserve, Cumbria. New Phytologist 90: 339-354.

Burenhuit G. 1980. The archaeological excavation at Carrowmore, Co. Sligo: Excavation seasons 1977-1979. Theses and papers in North European Archaeology 9

Buzer JS. 1980. Pollen analysis of sediments from Lough Ine and Ballyally Lough, Co. Cork, Ireland. New Phytologist 86: 93-108.

Carter RWG. 1975a. Recent changes in the coastal geomorphology of the Magilligan Foreland, Co. Londonderry. Proceedings of the Royal Irish Academy 75B: 469-497.

Carter RWG. 1982a. Sea-level changes in Northern Ireland. Proceedings of the Geologists Association, London 93: 7-23.

Carter RWG, Orford JD. 1982. The south and east coasts of Co. Wexford. Field Guide no.4. Irish Association for Quaternary Studies (IQUA): Dublin

Carter RWG, Devoy RJN, Shaw J. 1989a. Late Holocene sea levels in Ireland. Journal of Quaternary Science 4(1): 7-24.

Carter RWG, Wilson P. 1990. Portstewart Strand and the Bann Estuary. In: North Antrim and Londonderry, Field Guide 13, Wilson P (ed.). Irish Association For Quaternary Studies; Dublin: 18-23.

Clark et al. (submitted)

Colhoun EA, Ryder AT, Stephens N. 1973. ${ }^{14} \mathrm{C}$ age of an oak-hazel forest bed at Drumskellan, Co. Donegal and its relations to the late-Midlandian and Littletonian raised beaches. Irish Naturalists Journal 17: 321-327.

Devoy RJN, Delaney C, Carter RWG, Jennings SC. 1996. Coastal stratigraphies as indicators of environmental changes upon European Atlantic coasts in the late Holocene. Journal of Coastal Research 12: 564-588.

Devoy RJN, Nichol SL, Sinnott AM. 2004. Holocene sea-level and sedimentary changes on the south coast of Ireland. Journal of Coastal Research 39 (special issue)

Donner J, Jungner H. 1980. Radiocarbon ages of shells in Holocene marine deposits. Radiocarbon 22: 556-561.

Dresser PQ. 1980. Dublin radiocarbon dates III. Radiocarbon 22: 1028-1030.

Dresser PQ, Smith AG, Pearson GW. 1973. Radiocarbon dating of the raised beach at Woodgrange, Co. Down. Proceedings of the Royal Irish Academy 73B: 53-56.

Gaulin C, Delibrais G, Denèfle M. 1983. Analyse pollinique et detation par le ${ }^{14} \mathrm{C}$ d'une tourbiere submergée de l'age de Bronze dans le Nord-Ouest de l'Lande (presqu'île de Termon. Dungloe, Comte Donegal). Comptes Rendus de l'Académie des Sciences Paris 296, II, 305-307. 
Gehrels R. 2004. Saltmarsh fieldwork, stratigraphy, micropalaeontology, transfer functions: Ireland. In Late Holocene Shallow Marine Environments Of Europe (HOLSMEER) final Report, Scourse J (ed.): 107-120.

Harkness DD, Wilson HE. 1979. Scottish Universities Research and Reactor Centre radiocarbon measurements III. Radiocarbon 21: 203-256.

Harmon M. 2006. Saltmarsh Archives of Relative Sea-Level Change During the Late Holocene in the North of Ireland. Unpublished PhD thesis, Queens University Belfast.

Healy MG. 1995. The lithostratigraphy and biostratigraphy of a holocene coastal sediment sequence in Marazion Marsh, west Cornwall, U.K. with reference to relative sea-level movements. Marine Geology 124: 237-252.

Heyworth A, Kidson C. 1982. Sea-level changes in southwest England and Wales. Proceedings of the Geologists' Association 93: 91-111.

Harris CR. 1979a. Flandrian sediments and microfauna in Dublin Bay, Ireland. Unpublished PhD thesis. University of Dublin (TCD)

Hubbs CL, Bien GS, Suess HE. 1965. Radiocarbon 7: 66.

Huddart D. 1992. Coastal environmental changes and morphostratigraphy in southwest Lancashire, England. Proceedings of the Geologists Association 103: 217-236.

Jessen K. 1949. Studies in late Quaternary deposits and flora history of Ireland. Proceedings of the Royal Irish Academy 52B: 85-290.

Kidson C, Heyworth A. 1982. Sea-level changes in southwest England and Wales, Proceedings of the Geologists Association 93: 91-112.

Liversage GD. 1968. Excavations at Dalkey Island, Co. Dublin, 1956-1959. Proceedings of the Royal Irish Academy 66C: 53-223.

Maloney BK. 1985. A Palaeoecological investigation of the Holocene back-barrier environment near Carnsore Point, Co. Wexford. Proceedings of the Royal Irish Academy 85B: 73-89.

Manning PI, Robbie JA, Wilson HE. 1970. The geology of Belfast and the Lagan Valley. Memoirs of the Geological Survey Northern Ireland.

McCabe AM, Haynes JR, Macmillan NF. 1986. Late-Pleistocene tidewater glaciers and glaciomarine sequences from north County Mayo, Republic of Ireland. Journal of Quaternary Science 1: 73-84.

McCabe AM, Haynes JR. 1996. A late Pleistocene intertidal boulder pavement from an isostatically emergent coast, Dundalk Bay, eastern Ireland. Earth Surface Processes and Landforms 21: 555-572.

McCabe AM, Clark PU. 1998. Ice sheet variability around the North Atlantic Ocean during the last deglaciation. Nature 392: 373-377.

McCabe AM, Clark PU. 2003. Deglacial chronology from County Donegal, Ireland: implications for deglaciation of the British-Irish ice sheet. Journal of the Geological Society of London 160: 847-855. 
McCabe AM, Clark PU, Clark C. 2005. AMS 14C dating of deglacial events in the Irish Sea Basin and other sectors of the British-Irish ice sheet. Quaternary Science Reviews 24: 16731690.

Mitchell GF. 1971. The Larnian culture: A minimal view. Proceedings of the Prehistoric Society 38: 274-283.

Mitchell GF. 1976. The Irish Landscape. Collins: London.

Mitchell GF. 1977. Raised Beaches and Sea Levels. In British Quaternary Studies-recent advances, Shotton FW (ed.). Clarendon Press: Oxford; 169-186.

Mitchell GF. 1981b. The Littletonian warm stage - post 10,000 BP. In A Geology of Ireland, Holland CH (ed.). Scottish University Press: Edinburgh; 235-238.

Mitchell GF, Stephens N. 1974. Is there evidence for a Holocene sea-level higher than that of today on the coasts of Ireland? Coll. Int. CNRS 219: 115-125

Morrison MES, Stephens N. 1961. Stratigraphy and pollen analysis of the raised beach deposits at Ballyhalbert, Co. Down. New Phytologist 59: 153-162.

Morrison MES, Stephens N. 1965. A submerged Late Quaternary deposit at Roddans Port on the northeast Coast of Ireland. Philosophical Transactions of the Royal Society, London 249B: 221-255.

Naylor D. 1965. Pleistocene and Post-Pleistocene sediments in Dublin Bay. Scientific Proceedings of the Royal Dublin Society Series A(2): 175-188.

O'Connell M. 1988. Streamstown Bay - partially submerged peat as evidence for later postglacial sea-level change. In IQUA Field Guide no. 11 Connemara, O'Connell M, Warren WP (eds.). Irish Association for Quaternary Studies (IQUA): Dublin; 45-49.

Orford JD, Carter RWG. 1982b. Geomorphological changes on the barrier coast of south Wexford. Irish Geography 15: 70-84.

O'Sullivan A. 2001. Foragers, farmers and fishers in a coastal landscape: An intertidal archaeological survey of the Shannon estuary. Royal Irish Academy: Dublin.

Pearson GW. 1979. Belfast radiocarbon dates IX. Radiocarbon 21: 274-290.

Pearson GW, Pilcher JR. 1975. Belfast radiocarbon dates VIII. Radiocarbon 17: 226-238.

Penney D. 1983. Post Glacial sediments and foraminifera at Dundalk, Ireland. Unpublished PhD Thesis, Trinity College Dublin.

Prior DB. 1966. Late glacial and post-glacial shorelines in north-east Antrim. Irish Geography 5: 173-187.

Prior DB, Holland S, Cruickshank MM. 1981. A preliminary report on late Devensian and early Flandrian deposits at Carnlough, Co. Antrim. Irish Geography 14: 75-84.

Roberts DH, Chiverrell RC. Innes JB, Horton, BP, Brooks, AJ, Thomas GSP, Turner S, Gonzalez S. (submitted). Holocene sea levels, Last Glacial Maximum deglacial environments and geophysical models in the northern Irish Sea Basin, UK. 
Scourse J, Austin WEN. 1994. A Devensian Late-glacial and Holocene sea-level and water depth record from the Central Celtic Sea. Quaternary Newsletter 74: 22-29.

Shaw J. 1985. Holocene coastal evolution, Co. Donegal, Ireland. Unpublished PhD Thesis, Coleraine, The University of Ulster.

Shaw J, Carter RWG, 1994. Coastal peats from northwest Ireland: implications for Late Holocene RSL change and shoreline evolution. Boreas 23: 74-91.

Shennan I, Bradley S, Milne G, Brooks AJ, Bassett S, Hamilton S, Hillier C, Hunter A, Woodal R. (submitted). Relative sea-level changes, glacial isostatic modelling and ice sheet reconstructions from the British Isles since the last glacial maximum

Singh G, Smith AG. 1973. Post Glacial vegetational history and relative land and sea level changes in Lecale, Co. Down. Proceedings of the Royal Irish Academy 73B: 1-51.

Sinnott A. 1999. Holocene Sea-Level Changes From the South and Southeast Coasts of Ireland. Unpublished PhD Thesis, University College Cork, NUIC.

Smith AG, Pilcher JR. 1973. Radiocarbon dates and vegetational history of the British Isles. New Phytologist 72: 903-914.

Smith AG, Pearson GW, Pilcher JR. 1974. Belfast radiocarbon dates VII, Radiocarbon 16: 269276.

Stephens N, Collins AEP. 1960. The Quaternary deposits at Ringneill Quay and Ardmillan, Co. Down. Proceedings of the Royal Irish Academy 61C: 41-77.

Stillman CJ. 1968. The post-glacial change in sea level in southwest Ireland: new evidence from freshwater deposits on the floor of Bantry Bay. Scientific Proceedings of the Royal Dublin Society 3A: 125-127.

Telford MB. 1978. Glenveagh Forest Park: The past and present vegetation. Unpublished PhD thesis, Trinity College, Dublin.

Tooley MJ. 1977. The Isle of Man, Lancashire Coast and Lake District, Field Guide A4, X INQUA Congress, Geo. Abstracts Ltd: Norwich.

Tooley MJ. 1978a. Sea-Level Changes in North-West England During the Flandrian Stage. Clarendon Press: Oxford; 69-86.

Tooley M.J. 1978c. Interpretation of Holocene sea-level changes, Geologiska Foreningens I Stockholm Forhandlingar 100: 203-212.

Tooley MJ. 1985. Sea-level changes and coastal morphology in North-West England. In The Geomorphology of North-West England, Johnson RH (ed.) Manchester University Press, Manchester; 94-121.

Trautman MA, Willis EH. 1966. Radiocarbon 8: 161-203.

Wilson HE. 1972. Regional geology of Northern Ireland. HMSO.

Zong Y, Tooley M. 1996. Holocene sea-level changes and crustal movements in Morecambe Bay, Northwest England, Journal of Quaternary Science 11: 43-58. 